\title{
Evidence for heterogeneous chlorine activation in the tropical UTLS
}

\author{
M. von Hobe ${ }^{1}$, J.-U. Grooß ${ }^{1}$, G. Günther ${ }^{1}$, P. Konopka ${ }^{1}$, I. Gensch ${ }^{1}$, M. Krämer ${ }^{1}$, N. Spelten ${ }^{1}$, A. Afchine ${ }^{1}$, \\ C. Schiller ${ }^{1}$, A. Ulanovsky ${ }^{2}$, N. Sitnikov ${ }^{2}$, G. Shur ${ }^{2}$, V. Yushkov ${ }^{2}$, F. Ravegnani ${ }^{3}$, F. Cairo ${ }^{3}$, A. Roiger ${ }^{4}$, C. $_{\text {. }}$ Voigt $^{4}$, \\ H. Schlager ${ }^{4}$, R. Weigel ${ }^{5}$, W. Frey ${ }^{5}$, S. Borrmann ${ }^{5}$, R. Müller ${ }^{1}$, and F. Stroh ${ }^{1}$ \\ ${ }^{1}$ Forschungszentrum Jülich GmbH, Institute for Energy and Climate Research - Stratosphere (IEK-7), Jülich, Germany \\ ${ }^{2}$ Central Aerological Observatory, Dolgoprudny, Moscow, Russia \\ ${ }^{3}$ Institute of Atmospheric Sciences and Climate CNR-ISAC, Bologna, Italy \\ ${ }^{4}$ Deutsches Zentrum für Luft und Raumfahrt, Institut für Physik der Atmosphäre, Oberpfaffenhofen, Germany \\ ${ }^{5}$ Johannes Gutenberg Universität Mainz, Institute of Atmospheric Physics, Mainz, Germany
}

Received: 2 June 2010 - Published in Atmos. Chem. Phys. Discuss.: 29 July 2010

Revised: 4 January 2011 - Accepted: 5 January 2011 - Published: 12 January 2011

\begin{abstract}
Airborne in-situ observations of $\mathrm{ClO}$ in the tropics were made during the TROCCINOX (Aracatuba, Brazil, February 2005) and SCOUT-O 3 (Darwin, Australia, November/December 2005) field campaigns. While during most flights significant amounts of $\mathrm{ClO}(\approx 10-20$ parts per trillion, ppt) were present only in aged stratospheric air, instances of enhanced $\mathrm{ClO}$ mixing ratios of up to $40 \mathrm{ppt}$ - significantly exceeding those expected from gas phase chemistry - were observed in air masses of a more tropospheric character. Most of these observations are associated with low temperatures or with the presence of cirrus clouds (often both), suggesting that cirrus ice particles and/or liquid aerosol at low temperatures may promote significant heterogeneous chlorine activation in the tropical upper troposphere lower stratosphere (UTLS). In two case studies, particularly high levels of $\mathrm{ClO}$ observed were reproduced by chemistry simulations only under the assumption that significant denoxification had occurred in the observed air. However, to reproduce the $\mathrm{ClO}$ observations in these simulations, $\mathrm{O}_{3}$ mixing ratios higher than observed had to be assumed, and at least for one of these flights, a significant denoxification is in contrast to the observed NO levels, suggesting that the coupling of chlorine and nitrogen compounds in the tropical UTLS may not be completely understood.
\end{abstract}

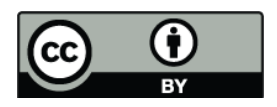

Correspondence to: $\mathrm{M}$. von Hobe (m.von.hobe@fz-juelich.de)

\section{Introduction}

Ozone trends in the tropopause region play an important role in the radiative forcing of the Earth's climate system (Ramaswamy et al., 2001). The causes for decreasing ozone trends in this region over the 1980s and 1990s have not yet been fully understood (WMO, 2006; Logan, 1999). While changes in transport in the lowermost stratosphere could explain at least part of the observed trend (Fusco and Salby, 1999; Salby and Callaghan, 2004; Hood and Soukharev, 2005), chemical ozone loss due to halogen chemistry is also thought to play a significant role (Salawitch et al., 2005; Solomon et al., 1997). Besides higher than previously suggested and still slightly increasing amounts of bromine in this region (Dorf et al., 2006), catalytic ozone destruction by $\mathrm{ClO}$ produced as a result of heterogeneous chlorine activation on sulphate aerosol and on ice-particles in cirrus clouds has been suggested (Borrmann et al., 1996, 1997; Bregman et al., 2002; Keim et al., 1996; Solomon et al., 1997; Thornton et al., 2003, 2005).

Known reactions by which chlorine can be heterogeneously activated are

$$
\begin{aligned}
& \mathrm{HCl}+\mathrm{ClONO}_{2} \rightarrow \mathrm{Cl}_{2}+\mathrm{HNO}_{3} \\
& \mathrm{HCl}+\mathrm{HOCl} \rightarrow \mathrm{Cl}_{2}+\mathrm{H}_{2} \mathrm{O} \\
& \mathrm{H}_{2} \mathrm{O}+\mathrm{ClONO}_{2} \rightarrow \mathrm{HOCl}+\mathrm{HNO}_{3} \\
& \mathrm{HCl}+\mathrm{HOBr} \rightarrow \mathrm{H}_{2} \mathrm{O}+\mathrm{BrCl}
\end{aligned}
$$

Reaction (R1) was first suggested by Solomon et al. (1986) as a key process leading to the activation of the main chlorine reservoir species $\mathrm{HCl}$ and $\mathrm{ClONO}_{2}$ and subsequent rapid

Published by Copernicus Publications on behalf of the European Geosciences Union. 
ozone destruction in the Antarctic stratosphere in winter. This suggestion prompted numerous laboratory studies and the discovery of a number of further heterogeneous reactions of importance to stratospheric chemistry (e.g. Reactions R2$\mathrm{R} 4)$. Today, the reaction rates of heterogeneous reactions on a variety of surfaces are reasonably well constrained through laboratory studies (Sander et al., 2006). While polar stratospheric clouds (PSCs) occur in stratospheric air containing significant amounts of chlorine reservoir species (in the parts per billion, ppb range), the situation near the tropopause is different. Tropospheric aerosol number densities decrease sharply with altitude and water vapour saturation leading to cirrus formation is most likely to be found in humid tropospheric air masses, while sizeable amounts of inorganic chlorine $\left(\mathrm{Cl}_{\mathrm{y}}=\mathrm{HCl}+\mathrm{ClONO}_{2}+\mathrm{Cl}+\mathrm{ClO}+2 \mathrm{ClOOCl}+\right.$ $\mathrm{OClO}+\mathrm{HOCl}$ ) are present only in photochemically aged air masses of stratospheric origin, which on average are comparatively dry. Thus it has been pointed out that heterogeneous chlorine activation plays a significant role only in regions where wet tropospheric air masses are mixed with stratospheric air (e.g. Solomon et al., 1997). At mid and high latitudes, air with a significant stratospheric signature (characterised by high abundance of ozone) is often found below the thermal tropopause due to downward transport. In the tropics, the $\mathrm{Cl}_{\mathrm{y}}$ content inside high altitude cirrus clouds coupled to local deep convection is expected to be low and significant amounts of $\mathrm{Cl}_{\mathrm{y}}$ that can be activated by heterogeneous reactions are thought to be present only at the interface between the cloud and stratospheric air at the top of the cloud (Solomon et al., 1997). However, the amount of inorganic chlorine in the tropical upper troposphere and lower stratosphere (UTLS) resulting from the decomposition of very short lived species (VSLS) could be quite significant (e.g. WMO, 2006; Laube et al., 2008; Mébarki et al., 2010). This as well as the possibility of convective transport of inorganic chlorine $(\mathrm{HCl}, \mathrm{ClO}$, sea salt) from the marine boundary layer into the UTLS will be discussed in more detail in Sect. 2.2 and in the context of our results in Sect. 3.

Cirrus clouds extending up to or above the tropopause are most likely to be found in mid-latitudes $\left(45\right.$ to $65^{\circ}$ ) and in the inner tropics $\left(<10^{\circ}\right.$; Wang et al., 1996). The altitude of the tropopause in these regions is very different: typically 10 to $12 \mathrm{~km}$ in mid latitudes and 15 to $17 \mathrm{~km}$ in the tropics. Tropical Cirrus clouds are particularly widespread and often optically thin (Wang et al., 1996). For mid and high latitudes a number of observations of $\mathrm{ClO}$ near the tropopause exist and have been linked to heterogeneous activation on cirrus or background aerosol (Thornton et al., 2003; Borrmann et al., 1997; Keim et al., 1996; Stroh et al., 2004). Here we present observations of $\mathrm{ClO}$ from the TROCCINOX (Tropical Convection, Cirrus, and Nitrogen Oxides Experiment) and the $\mathrm{SCOUT}^{-} \mathrm{O}_{3}$ (Stratospheric-Climate links with emphasis On the Upper Troposphere and lower stratosphere) aircraft campaigns, which represent the first in-situ measurements of enhanced $\mathrm{ClO}$ in the UTLS in the tropics. In Sect. 3, we show that in some cases the observed $\mathrm{ClO}$ mixing ratios cannot be explained by gas phase chemistry alone, but are likely to be caused by heterogeneous reactions on cold sulphate aerosol or on cirrus ice particles. In particular, we investigate events of concurrent or preceding cirrus cloud formation both below the tropopause (TROCCINOX) and extending into the lowermost stratosphere $\left(\mathrm{SCOUT}-\mathrm{O}_{3}\right)$. The parameters that are most likely to influence the extent of heterogeneous chlorine activation are investigated. Case studies for incidences of unusually high $\mathrm{ClO}$ are presented, where observations are compared to model simulations of heterogeneous activation and chemical deactivation of active chlorine (Sect. 4).

\section{Experiment}

\subsection{Field observations}

Observations were made during two field campaigns with the M55-Geophysica, a Russian research aircraft with a ceiling altitude of about $21 \mathrm{~km}$. In February 2005, the aircraft was deployed from Araçatuba, Brazil, during the TROCCINOX campaign. Observations inside cirrus clouds were made during several flights in the altitude range $10-15 \mathrm{~km}$ (see Huntrieser et al., 2007, and Konopka et al., 2007, for detailed information on all flights and meteorological conditions). During the $\mathrm{SCOUT}^{-\mathrm{O}_{3}}$ campaign in November/December 2005, flights were carried out from Darwin, Australia. Convective storms reaching altitudes of up to $20 \mathrm{~km}$ were observed, and cirrus clouds were found above the tropopause at altitudes as high as $17 \mathrm{~km}$ (for information on flights and meteorology see Brunner et al., 2009).

Chlorine monoxide $(\mathrm{ClO})$ was measured by the HALOX instrument situated in a pod underneath the left wing of the Geophysica aircraft (von Hobe et al., 2005). It employs the chemical conversion resonance fluorescence (CCRF) technique described by Brune et al. (1989). Through an inlet optimised for radical measurements, ambient air is pulled through two measurement ducts where periodically (10 or 20 s cycles) $\mathrm{NO}$ is added, converting $\mathrm{ClO}$ to $\mathrm{Cl}$ atoms that are detected downstream by resonance fluorescence in the vacuum UV. Accuracy is estimated to be $\approx 16 \%$, resulting from uncertainties in the $\mathrm{Cl}$ atom VUV $(118.9 \mathrm{~nm})$ absorption coefficient (Schwab and Anderson, 1982), the scattering characteristics of the RF cell, the contribution of the Lyman- $\alpha$ spectral line to the lamp output, and the $\mathrm{ClO}$ to $\mathrm{Cl}$ chemical conversion efficiency. More critical for the analysis presented below is precision, which is influenced largely by the output and stability of the chlorine emission lamps and the detector noise observed. These parameters varied during both campaigns and were generally better during TROCCINOX. The signal-to-noise-ratio can be increased by integrating the signal over several NO addition cycles, resulting in a better precision at the expense of time resolution. For the data presented here, the number of cycles averaged was determined for each flight - and in some cases flight 
segment - individually so that mixing ratios in the range of only a few ppt present in the tropical UTLS could be detected with reasonable precision (ranging from $\approx 10$ to $50 \%$ ) and a time resolution (2-10 min during TROCCINOX and 130 min during $\mathrm{SCOUT}^{-\mathrm{O}_{3}}$ ) on the same order as individual cirrus events observed by other instruments. HALOX also measures $\mathrm{BrO}$ at ambient pressures below $\sim 100 \mathrm{hPa}$ (this limit arises due to strong $\mathrm{O}_{2}$ absorption in the spectral region used for HALOX BrO measurements). However, for the flights considered here, the BrO signal was always below the detection limit of $\sim 4 \mathrm{ppt}$.

Ozone measurements were performed by the FOZANII (Fast Ozone Analyzer) instrument jointly developed and operated by the Central Aerological Observatory, Russia, and Institute of Atmospheric Science and Climate, Italy (Ulanovsky et al., 2001; Yushkov et al., 1999). It has two channels with solid state chemiluminescent sensors and measures ozone in the concentration range of 10$500 \mu \mathrm{g} / \mathrm{m}^{3}$ (corresponding to about 50-2500 ppb for the pressures and temperatures in the tropical UTLS) with a time resolution of $1 \mathrm{~s}$ and a precision of $<10 \%$ at ambient pressures between 30 and $1000 \mathrm{hPa}$. FOZAN is equipped with a high accuracy ozone generator for periodic calibration of each channel every $15 \mathrm{~min}$.

$\mathrm{NO}_{\mathrm{y}}$ and NO were determined by the SIOUX (Stratospheric observation unit for nitrogen oxides) instrument. SIOUX includes two channels for detection of nitric oxides (NO), total reactive nitrogen $\left(\mathrm{NO}_{\mathrm{y}}\right)$, and $\mathrm{NO}_{\mathrm{y}}$ contained in particles larger than about $1 \mu \mathrm{m}$ in diameter (Schmitt, 2003; Voigt et al., 2005). The detection of $\mathrm{NO}$ is based on $\mathrm{NO} / \mathrm{O}_{3}-$ chemiluminescence. Higher oxidized $\mathrm{NO}_{\mathrm{y}}$ species are reduced to NO using a heated $\mathrm{Au}$ converter and $\mathrm{CO}$ gas as catalyst. Particle-phase $\mathrm{NO}_{\mathrm{y}}$ is detected by oversampling of particles in a forward facing subisokinetic inlet and evaporation and reduction of condensed $\mathrm{NO}_{\mathrm{y}}$ in the heated inlet and Au converter (Voigt et al., 2007). The nominal accuracy and precision of the gas-phase measurements are $10 \% / 5 \%$ (NO) and $15 \% / 7 \%\left(\mathrm{NO}_{\mathrm{y}}\right)$.

Evidence for cirrus clouds and potential recent heterogeneous processing is gathered from observations of water vapour and particles. Total water, i.e. gas phase and condensed phase, was determined with a measurement frequency of $1 \mathrm{~s}^{-1}$ by the Fast In situ Stratospheric Hygrometer (FISH) based on the Lyman- $\alpha$ photofragment fluorescence technique. Details of the instrument and the calibration procedure are described in Zöger et al. (1999). To detect and quantify water in the condensed phase, the saturation water vapour at the given pressure and temperature was subtracted from the total water (Schiller et al., 2008). The FISH measurements made during the TROCCINOX and SCOUT$\mathrm{O}_{3}$ campaigns have recently been published by Schiller et al. (2009).

In addition, gas phase water vapour was determined by the Fluorescent Airborne Stratospheric Hygrometer (FLASH) developed in Central Aerological Observatory (Sitnikov et al., 2007). As is the FISH instrument, it is based on Lyman$\alpha$ photofragment fluorescence method. The inlet minimizes the influence of the condensed water phase.

Further evidence for the presence and nature of particles is obtained from the Multiwavelength Aerosol Scatterometer (MAS) (Buontempo et al., 2006) observations of volume depolarisation at $532 \mathrm{~nm}$. MAS is a laser backscatter sonde measuring in situ aerosol optical parameters, by revealing cross and direct polarisation backscattered light at different wavelengths. During daytime, only the $532 \mathrm{~nm} \mathrm{Nd-}$ YAG-diode pumped laser has sufficient energy to detect the backscattered signal.

Cloud particles in the size range 2.7 to $31 \mu \mathrm{m}$ diameter (for the relevant flight section on 19 November it is unclear whether the upper size limit was 31 or $44 \mu \mathrm{m}$ due to instrumental problems) were measured using a Forward Scattering Spectrometer Probe (FSSP-100) as described by de Reus et al. (2009).

Aerosol number densities in the size range from $6 \mathrm{~nm}$ up to $1 \mu \mathrm{m}$ particle diameter were measured by the Condensation Particle Counting System (COPAS) (Weigel et al., 2009) consisting of an aerosol inlet and two dual-channel continuous flow Condensation Particle Counters (CPCs). Three channels are operated with distinct temperature differences between the saturator and the condenser block, yielding smallest detectable particle sizes of $6 \mathrm{~nm}, 11 \mathrm{~nm}$, and $15 \mathrm{~nm}$, respectively, at ambient pressure of $70 \mathrm{hPa}$. The fourth channel is operated with an aerosol heating line for a determination of the number of non-volatile particles.

Temperature and pressure were measured using commercial Rosemount sensors. Geolocation data were provided by the M-55 avionic system.

\subsection{Estimation of available inorganic chlorine $\left(\mathrm{Cl}_{\mathbf{y}}\right)$}

Ideally, $\mathrm{Cl}_{\mathrm{y}}$ is determined by measuring all inorganic chlorine compounds, i.e. $\mathrm{HCl}, \mathrm{ClONO}_{2}, \mathrm{Cl}_{2}, \mathrm{ClO}, \mathrm{OClO}$, $\mathrm{HOCl}$, and $\mathrm{Cl}_{2} \mathrm{O}_{2}$. Unfortunately, during TROCCINOX and $\mathrm{SCOUT}_{-} \mathrm{O}_{3}, \mathrm{ClO}$ was the only measured inorganic chlorine species. Thus $\mathrm{Cl}_{\mathrm{y}}$ must be estimated differently. Here we use correlations with other tracers, based on the fact that the amount of $\mathrm{Cl}_{\mathrm{y}}$ in a particular air mass increases with photochemical aging, and is higher for stratospheric air than for tropospheric air. A fairly accurate method for estimating stratospheric $\mathrm{Cl}_{\mathrm{y}}$ is provided by Woodbridge et al. (1995) based on measurements of the most abundant organic chlorine compounds. For TROCCINOX and SCOUT-O 3 , only the long-lived CFC-11 and CFC-12, with respective lifetimes of 45 and 100 years (WMO, 2006), were measured with adequate time resolution by the HAGAR in-situ gas chromatograph. The fractional release of chlorine from these two gases is small $(<5 \%)$ for young air typically found in the tropical UTLS (Laube et al., 2010), with a much larger fraction of $\mathrm{Cl}_{\mathrm{y}}$ coming from $\mathrm{CH}_{3} \mathrm{Cl}, \mathrm{CCl}_{4}$ and very short lived species (VSLS) in these air masses (Laube et al., 2008). 
Thus, a correlation with a shorter-lived tracer seems more appropriate to estimate $\mathrm{Cl}_{\mathrm{y}}$.

Therefore, we estimate $\mathrm{Cl}_{\mathrm{y}}$ from observed $\mathrm{O}_{3}$ adopting the approach by Thornton et al. (2005). To derive a correlation representative for the region and time of our measurements, we used ACE-FTS (Atmospheric Chemistry Experiment - Fourier Transform Spectrometer, Bernath et al., 2005) satellite observations of $\mathrm{O}_{3}$ and $\mathrm{HCl}$ in the latitude band $30^{\circ} \mathrm{N}-30^{\circ} \mathrm{S}$ made between November 2004 and February 2006. On average these data yield a robust linear correlation (Fig. 1a) in fair agreement with $\mathrm{O}_{3}-\mathrm{HCl}$ relationships shown by Marcy et al. (2004). However, for $x\left(\mathrm{O}_{3}\right)<100 \mathrm{ppb}$ variability is high, with $x(\mathrm{HCl})=15 \pm 52 \mathrm{ppt}$ (mean and standard deviation), and the correlation tends to yield very low or even negative $\mathrm{HCl}$ mixing ratios. Therefore, $x(\mathrm{HCl})$ was set constant to $27 \mathrm{ppt}$ below $100 \mathrm{ppb} \mathrm{O}_{3}$ (27 ppt is used to avoid a discontinuity at $100 \mathrm{ppb} \mathrm{O}_{3}$ where the correlation yields $27 \mathrm{ppt}$ ). This value is in excellent agreement with balloon borne $\mathrm{HCl}$ observations for typical background conditions in the tropical UTLS (Mébarki et al., 2010). Using ACEFTS measurements of a large number of inorganic and organic chlorine containing trace gases in the tropics averaged over the period of February 2004 to January 2005 (Nassar et al., 2006), a relationship between $x(\mathrm{HCl})$ and $x\left(\mathrm{Cl}_{\mathrm{y}}\right)$ is established (Fig. 1b). Combining the two correlations yields $x\left(\mathrm{Cl}_{\mathrm{y}}\right)=8.3 \times 10^{-4} x\left(\mathrm{O}_{3}\right)-0.033 \mathrm{ppb}$ for $x\left(\mathrm{O}_{3}\right)>100 \mathrm{ppb}$, and $x\left(\mathrm{Cl}_{\mathrm{y}}\right)=50 \mathrm{ppt}$ for $x\left(\mathrm{O}_{3}\right)<100 \mathrm{ppb}$. This compares well with mid latitude observations (Avallone et al., 1993), where $x\left(\mathrm{Cl}_{\mathrm{y}}\right) \approx 0.001 x\left(\mathrm{O}_{3}\right)$. Obviously, the uncertainty in this relationship is rather large, particularly for air with $x\left(\mathrm{O}_{3}\right)<100 \mathrm{ppb}$ (Fig. 1a), where both measurement uncertainties and real relative variability are greatest. In particular, the high scatter in the "low-ozone" ACE-FTS HCl data may partly originate from local variable sources of $\mathrm{Cl}_{\mathrm{y}}$. These may include very short lived halogenated substances (VSLS) as well as inorganic chlorine species. For the VSLS, Laube et al. (2008) measured $47.1 \pm 5.7 \mathrm{ppt} \mathrm{Cl}$ in the tropical tropopause layer (TTL), in agreement with a range of 52$60 \mathrm{ppt}$ for the estimated tropical upper tropospheric mixing ratio given in WMO (2006). For typical background conditions in the TTL, an upper limit for $\mathrm{HCl}$ of 20-30 ppt has been determined by Mébarki et al. (2010). An additional $33 \pm 11 \mathrm{ppt} \mathrm{Cl}$ have been suggested to be present in the form of phosgene $\left(\mathrm{COCl}_{2}\right)$, a reasonably stable inorganic intermediate of VSLS degradation (Fu et al., 2007).

Taking the sum of inorganic chlorine and VSLS in the tropical upper troposphere, and judging from the range of scatter in Fig. 1a, $x\left(\mathrm{Cl}_{\mathrm{y}}\right)$ seems unlikely to exceed $\approx 150 \mathrm{ppt}$ in tropospheric air $\left(x\left(\mathrm{O}_{3}\right)<100 \mathrm{ppb}\right)$, which, as will be shown below, is clearly too low to explain some of the observations of enhanced $\mathrm{ClO}$ by pure gas phase chemistry. A possible role of locally enhanced $x\left(\mathrm{Cl}_{\mathrm{y}}\right)$ due to rapid convective transport of inorganic chlorine compounds (e.g. $\mathrm{HCl}$, $\mathrm{ClO}$, sea salt) directly from the marine boundary layer will also be discussed in Sect. 3 .
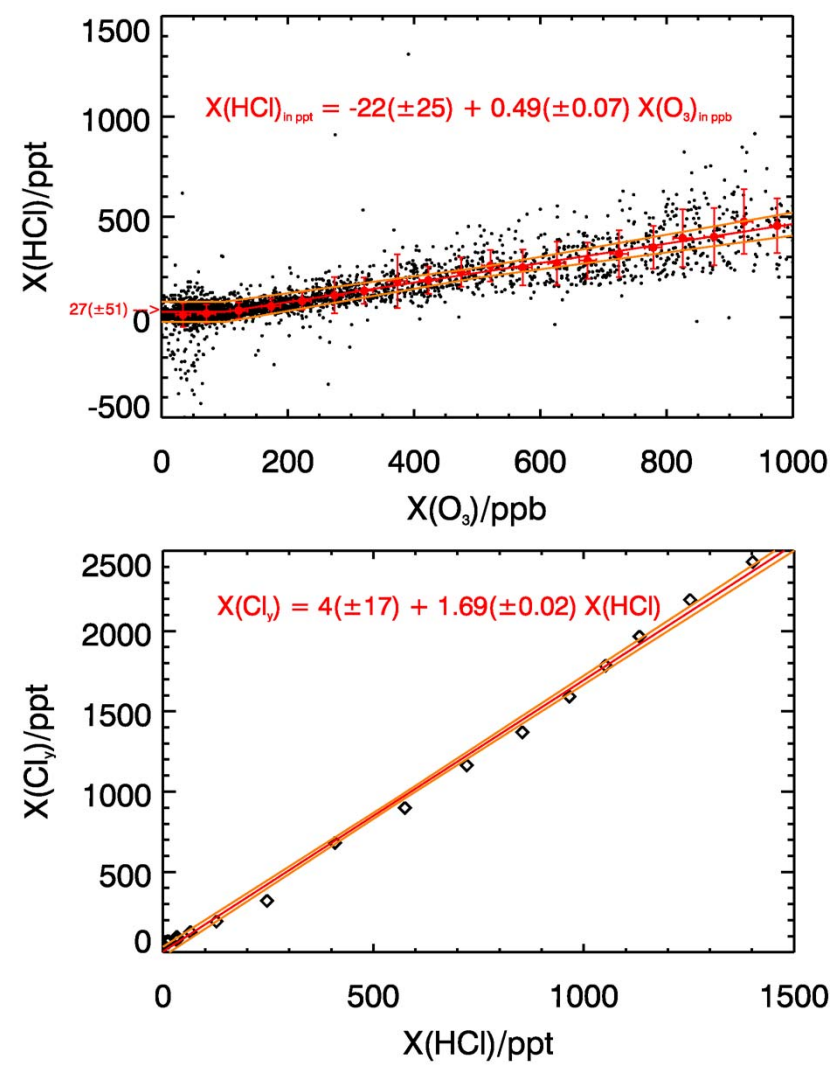

Fig. 1. Correlations used to estimate $\mathrm{Cl}_{\mathrm{y}}$ from $\mathrm{O}_{3}$. (a) Correlation of $\mathrm{HCl}$ vs. $\mathrm{O}_{3}$ based on ACE-FTS satellite observations (Version 2.2-update) in the latitude band $30^{\circ} \mathrm{N}-30^{\circ} \mathrm{S}$ between November 2004 and February 2006 (black symbols) averaged in 50 ppb $\mathrm{O}_{3}$ bins (red symbols with $1 \sigma$-error bars for $\mathrm{HCl}$ and $\mathrm{O}_{3}$ ). (b) Correlation of $\mathrm{Cl}_{\mathrm{y}}$ vs. $\mathrm{HCl}$ based on the tropical $\left(30^{\circ} \mathrm{N}-30^{\circ} \mathrm{S}\right)$ chlorine inventory (based on ACE-FTS measurements of a large number of inorganic and organic chlorine containing trace gases from February 2004-January 2005) recently published by Nassar et al. (2006).

\subsection{CLaMS modelling studies}

The Chemical Lagrangian Model of the Stratosphere (CLaMS) (Konopka et al., 2004; McKenna et al., 2002a, b) is a hierarchy of models ranging from a box model to a 3-D Chemistry Transport Model (CTM) based on a Lagrangian transport concept in which the chemical evolution within individual air parcels is simulated along their trajectories, which are determined from ECMWF temperature data and wind fields. For this study the CLaMS modules are used in three different modes:

- CLaMS_ST: the stationary mode with no transport and no mixing, where the air parcels stay at constant location and the chemical composition is influenced only by the diurnal photochemical cycle. This mode is used to derive typical noontime $\mathrm{ClO}$ mixing ratios and chlorine activation. 
- CLaMS_CTM: the 3-D CTM mode, in which advection and mixing are calculated. No detailed chemistry is calculated for simulations in the CTM mode. The focus of this simulation is on water vapour and the development of ice particles that form cirrus clouds. For this purpose, a novel CLaMS module to estimate Ice Water Content was employed. This module computes the conversion between gas phase water and ice water utilizing a temperature-dependent value for saturation over ice derived from freezing measurements in a simulation chamber (Gensch et al., 2008; Krämer et al., 2009; Möhler et al., 2005). Ice crystal number densities are parameterised as described in these references.

- CLaMS_BT: the back-trajectory mode, in which the full photochemistry is simulated along trajectories that end on selected points on the flight path. This mode is used for the case studies in this paper.

\subsubsection{Estimation of typical noontime chlorine activation}

We estimate typical noontime $\mathrm{ClO}$ mixing ratios - with and without heterogeneous activation - using the stationary box model simulation CLaMS_ST for the Darwin location of $13^{\circ} \mathrm{S} / 131^{\circ} \mathrm{E}$ (for simplicity, we used this location for both campaigns in CLaMS_ST) and different $\mathrm{O}_{3}$ mixing ratios from 1 to $1300 \mathrm{ppb}$ (the $\mathrm{O}_{3}$ mixing ratio was reset to its initial value after each diurnal cycle, as otherwise $\mathrm{O}_{3}$ accumulated significantly over the course of the simulation). To approximately represent the typical conditions encountered during TROCCINOX and SCOUT-O ${ }_{3}$, temperature, pressure, water vapour, and aerosol number densities were initialized from their relationship with ozone averaged over all relevant flights (Fig. 2a, b, d, e). $\mathrm{NO}_{\mathrm{y}}$, which plays a critical role for chlorine partitioning, was initialised using a midlatitude correlation from Michelson et al. (1998), which fits the $\mathrm{NO}_{\mathrm{y}}$ and $\mathrm{O}_{3}$ observations made during TROCCINOX and $\mathrm{SCOUT}-\mathrm{O}_{3}$ better than the tropical correlation from the same paper (Fig. 2c). This is probably caused by the fact that only a subset of flights during TROCCINOX and SCOUT-O were performed in tropical air masses (Brunner et al., 2009; Huntrieser et al., 2007). $\mathrm{Cl}_{\mathrm{y}}$ was initialised as a function of $\mathrm{O}_{3}$ as described in Sect. 2.2, with $\mathrm{HCl}$ being the only inorganic chlorine species present at the start of the model run. The simulation was run until the midday chlorine partitioning had reached equilibrium for all conditions (up to 30 iterative 1-day-cycles).

For heterogeneous chemistry in these simulations, ice formation was disabled and only reactions on liquid aerosol were simulated (this was done only for CLaMS_ST; ice formation and reactions on ice were allowed in the CLaMS_CTM and CLaMS_BT simulations, cf. below). Although unrealistic at low temperatures (ice formation is likely and often observed below $\approx 195 \mathrm{~K}$ ), this simplification does not significantly affect heterogeneous activation rates,

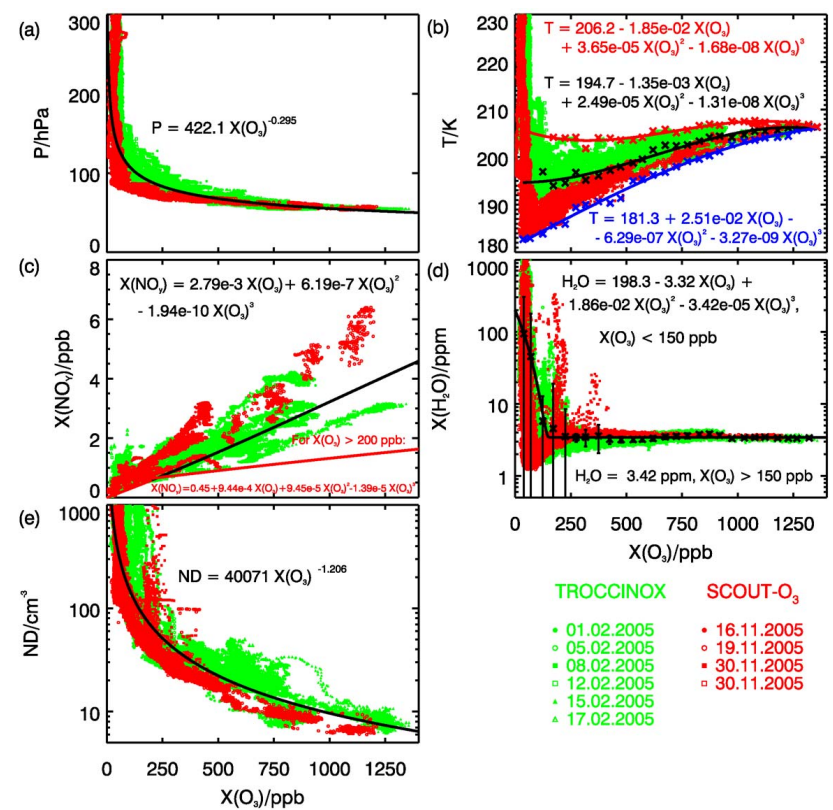

Fig. 2. Relationship of (a) pressure, (b) temperature, (c) $x\left(\mathrm{NO}_{\mathrm{y}}\right)$, (d) total water and (e) aerosol number densities with $\mathrm{O}_{3}$ observed during TROCCINOX (green symbols) and $\mathrm{SCOUT}_{3}$ (red symbols), used to initialise the CLaMS_ST simulation to estimate typical noontime $\mathrm{Cl}$ activation. Best fit relationships (lines) were determined for the measured data except for $x\left(\mathrm{NO}_{\mathrm{y}}\right)$ in panel (c), where correlations from Michelson et al. (1998) are shown.

because reactions 1 to 3 on liquid aerosol have a strong negative temperature dependence and reaction probabilities $\gamma$ below $195 \mathrm{~K}$ are comparable to those on ice surfaces for reactions 1 and 2 (Zhang et al., 1994; Hanson et al., 1994; Shi et al., 2001).

\subsubsection{Simulation of cirrus occurrence}

Gas phase water in CLaMS_CTM runs is initialised at the beginning of each simulation utilizing the specific humidity taken from ECMWF data. Boundaries are updated every CLaMS time step from ECMWF data as well. The formation of ice is parameterised either by using a conservative fixed value for saturation over ice of 100\% (like used by ECMWF until September 2006) or a temperature dependent parameterisation for heterogeneous freezing (Gensch et al., 2008; Krämer et al., 2008; Möhler et al., 2005). This parameterisation results in saturation values between 120 and $140 \%$ in the 180 to $230 \mathrm{~K}$ temperature range. Water vapour with values above these saturation levels is removed from the gas phase and added to the ice water content $x\left(\mathrm{H}_{2} \mathrm{O}\right)_{\text {cond }}$. Water vapour and ice water content are transported and mixed like any other tracer or chemical species. Evaporation at $100 \%$ saturation and sedimentation of ice are considered, the latter by assuming a uniform particle density and size distribution, thus parameterizing processes like re- and de-hydration. 


\subsubsection{Individual case study simulations}

For the case studies presented in Sect. 4, simulations using the ClaMS_BT mode were performed along 10-day-backtrajectories from locations along the flight path where significant $\mathrm{Cl}$-activation was observed. Observed temperatures were significantly colder than ECMWF temperatures. An offset was determined as the difference between observed temperature and ECMWF at the locations of observations and then subtracted for each air parcel individually from the temperatures along the whole trajectory. The offset varied from trajectory to trajectory, with average values of $-3.3 \pm 1.2 \mathrm{~K}$ (1 sigma) for all points of the 19 November flight and $-1.4 \pm 1.9 \mathrm{~K}$ (1 sigma) for the 30 November flight. The temperature offsets for the cases shown were $-2.9 \mathrm{~K}$ and $-2.1 \mathrm{~K}$, respectively.

Consistent with the above estimate, $x\left(\mathrm{Cl}_{\mathrm{y}}\right)$ was initialised to be $50 \mathrm{ppt}$ in the form of $\mathrm{HCl}$. Total $\mathrm{H}_{2} \mathrm{O}$ was initialised so that the observed total water measured by FISH at the end of the simulation is reasonably well reproduced. The high values of 10 and $30 \mathrm{ppm}$ and more are not unrealistic given the more tropospheric character of the air masses and the presence of ice particles expected to lead to considerable dehydration over the course of the simulations. The latter is supported by the CLaMS_CTM simulations. A significantly lower initial $\mathrm{H}_{2} \mathrm{O}$ mixing ratio in the CLaMS_BT runs would significantly reduce particle formation. SIOUX observations ( $510 \mathrm{ppt})$ were used to initialise $x\left(\mathrm{NO}_{\mathrm{y}}\right)$. Ozone was initialised from FOZAN observations $(\approx 50 \mathrm{ppb})$, but it was also varied for the sensitivity studies. $\mathrm{Br}_{\mathrm{y}}(=\mathrm{Br}+\mathrm{BrO}$ $+\mathrm{HBr}+\mathrm{BrONO}_{2}+\mathrm{BrCl}$ ) was set to $1 \mathrm{ppt}$, but also sensitivity studies with more $\mathrm{Br}_{\mathrm{y}}$ were performed. The remaining species were initialised from the Mainz 2-D model (Grooß et al., 1998).

Formation of and reactions on particles were treated by the CLaMS heterogeneous chemistry module that has been developed for reactions on stratospheric particles (McKenna et al., 2002a). To account for the different conditions in the tropical UTLS, the following adjustments were made:

- As in the stratosphere, the heterogeneous reactions were allowed to occur on ice and interstitial sulphate aerosol. Both particle types allow uptake of $\mathrm{HNO}_{3}$. The formation threshold for ice particles was parameterised according to freezing experiments in the AIDA chamber for coated soot particles as condensation nuclei (Gensch et al., 2008; Krämer et al., 2009; Möhler et al., 2005). These experiments resulted in a temperature-dependent threshold of around 50\% super-saturation for the observed temperatures.

- The interstitial sulphate aerosol was initialised with $0.1 \mathrm{ppb} \mathrm{H}_{2} \mathrm{SO}_{4}$ gas phase equivalent and an aerosol number density of $300 \mathrm{~cm}^{-1}$. In contrast to the stratospheric code, a typical ice particle radius of $10 \mu \mathrm{m}$ (Krämer et al., 2009) was defined and from that the particle number density (order of magnitude: $0.1 \mathrm{~cm}^{-3}$ ) was calculated using the steady state $x\left(\mathrm{H}_{2} \mathrm{O}\right)_{\text {cond }}$.

- Dehydration of the air due to particle sedimentation is simulated by a simple parameterisation that is linked to the particle settling velocity (Grooß et al., 2002). The characteristic height parameter was adjusted to $3.5 \mathrm{~km}$ such that the observed total $\mathrm{H}_{2} \mathrm{O}$ mixing ratio by FISH was reached towards the end of the simulation.

\section{Results}

Figure 3 shows that, during both campaigns, $\mathrm{ClO}$ generally increased together with ozone. During most flights, elevated $\mathrm{ClO}$ mixing ratios $(\approx 10-20 \mathrm{ppt})$ are found only in air masses with $\mathrm{O}_{3}$ mixing ratios higher than $\approx 300 \mathrm{ppb}$, i.e. containing any significant fraction of aged stratospheric air. This is consistent with the expected dependence of $\mathrm{ClO}$ on photochemical processing and available $\mathrm{Cl}_{\mathrm{y}}$ : mixing ratios found in stratospheric air did not significantly exceed typical noontime $\mathrm{ClO}$ levels expected from the known gas phase chemistry, which were estimated by the CLaMS_ST simulations for gas-phase only and are represented by the black line in Fig. 3, with the dark grey shading representing uncertainties due to time of day and temperature. Because of the strong correlation of available $\mathrm{Cl}_{\mathrm{y}}$ with ozone, the observations of significant $\mathrm{ClO}$ mixing ratio in these more stratospheric air masses do not represent a high degree of chlorine activation (Fig. 4).

From the CLaMS_ST gas phase simulations, $\mathrm{ClO}$ is expected to remain below $\approx 2 \mathrm{ppt}$ in air masses with a significant tropospheric fraction $\left(x\left(\mathrm{O}_{3}\right)<300 \mathrm{ppb}\right)$ in agreement with a large number of $\mathrm{ClO}$ observations at or below the HALOX detection limit. However, during a number of flights, significantly enhanced mixing ratios of up to $40 \mathrm{ppt}$ $\mathrm{ClO}$ were found, exceeding values expected for gas phase chemistry by about an order of magnitude. Only if heterogeneous chemistry is included in the CLaMS_ST simulations does the range of simulated noontime $\mathrm{ClO}$ mixing ratios - marked by the blue shaded area in Fig. 3 - correspond reasonably well to the high values that were sometimes observed, suggesting that heterogeneous reactions caused substantial production of active chlorine in the TTL. This seems quite realistic, because the low temperatures prevalent in the TTL will lead to relatively high heterogeneous reaction rates. Indeed, the highest degree of chlorine activation - given by the $x(\mathrm{ClO}) / x\left(\mathrm{Cl}_{\mathrm{y}}\right)$ ratio following Thornton et al. (2003) - was found in air masses with low ozone but also very low temperatures (Fig. 4), where heterogeneous reactions are most likely to play a relevant role. However, several incidences of enhanced $x(\mathrm{ClO}) / x\left(\mathrm{Cl}_{\mathrm{y}}\right)$ ratios were also observed at higher temperatures (Fig. 4) where heterogeneous activation may not be expected. To study this in more detail, we investigated the correspondence of $\mathrm{Cl}$ activation with indicators or preconditions for cirrus/ice particle presence 


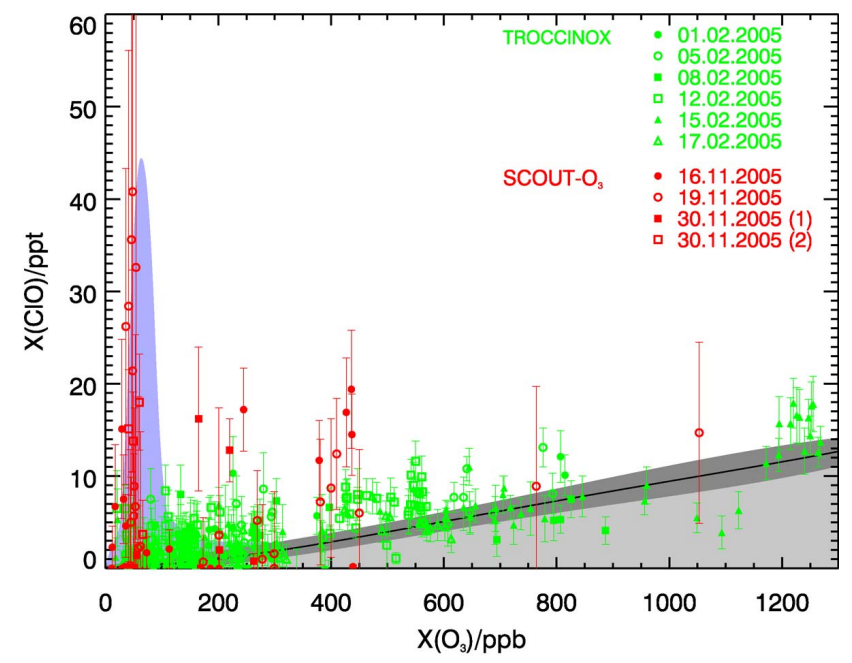

Fig. 3. Relation between $\mathrm{ClO}$ and Ozone in the tropical UTLS. Symbols represent HALOX measurements made during TROCCINOX and $\mathrm{SCOUT}_{-} \mathrm{O}_{3}$ field campaigns with error bars representing combined uncertainties from accuracy and precision. The black line shows $\mathrm{ClO}$ mixing ratios expected at local noon based on CLaMS_ST box-model simulations without heterogeneous reactions included; the range of values due to uncertainties in the $\mathrm{Cl}_{\mathrm{y}^{-}}$ $\mathrm{O}_{3}$ correlation and temperature is shown in dark grey. $\mathrm{ClO}$ mixing ratios observed at times significantly before or after local noon are expected to fall below this line as indicated by the light grey area. Blue shading indicates the range of $\mathrm{ClO}$ predicted with heterogeneous chemistry included; the upper limit is defined by the simulation with highest $\mathrm{Cl}_{\mathrm{y}}$ (Fig. 1) and lowest temperatures (Fig. 2b).

other than just the observed temperature. In the top panel of Fig. 5, the $\mathrm{ClO}$ data are marked simultaneous measurements of aerosol depolarization (MAS) and ice water content (FISH) as clear indicators for cirrus clouds encountered in-flight. Simulations of ice water content and temperature on back trajectories in the CLaMS_CTM mode provide an indication for potential recent cirrus formation. This is displayed in the middle panel and bottom panels of Fig. 5 respectively. In total there are 15 incidences of enhanced $\mathrm{ClO}$ with $x(\mathrm{ClO}) / x\left(\mathrm{Cl}_{\mathrm{y}}\right) \geq 0.15$, all of which are linked to either temperatures $<195 \mathrm{~K}$ and/or the occurrence of cirrus clouds during or preceding the flight. This is a strong indication that elevated $\mathrm{ClO}$ mixing ratios observed during TROCCINOX and $\mathrm{SCOUT}_{-} \mathrm{O}_{3}$ were caused by heterogeneous chlorine activation proceeding on cirrus ice particles and/or background aerosol at low temperatures. Transport of substantial amounts of $\mathrm{ClO}$ into the TTL from the stratosphere can be ruled out because this would also lead to an increase in $x\left(\mathrm{O}_{3}\right)$. Substantial mixing ratios of several hundred ppt inorganic chlorine have been observed in the marine boundary layer (Pszenny et al., 1993), but the supposition of rapid transport to the TTL seems unwarranted because of loss by wet deposition (e.g. Crutzen and Lawrence, 2000; Mari et al., 2000). A contribution of chlorine from sea salt aerosol
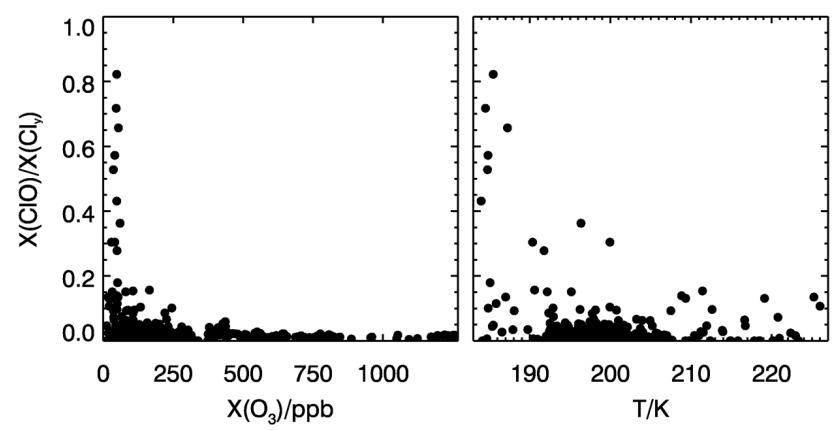

Fig. 4. Dependence of $\mathrm{ClO} / \mathrm{Cl}_{\mathrm{y}}$ on temperature and $\mathrm{O}_{3}$ at time of observation. $\mathrm{X}(\mathrm{ClO}) / \mathrm{X}\left(\mathrm{Cl}_{\mathrm{y}}\right)$ is calculated from HALOX $\mathrm{ClO}$ observations and $\mathrm{Cl}_{\mathrm{y}}$ estimates as described in Sect. 2.1, so uncertainties in this quantity will be rather large. Nevertheless, observed enhancements compared to the typical gas phase $\mathrm{ClO} / \mathrm{Cl}_{\mathrm{y}}$ ratios are significant for the majority of data points.

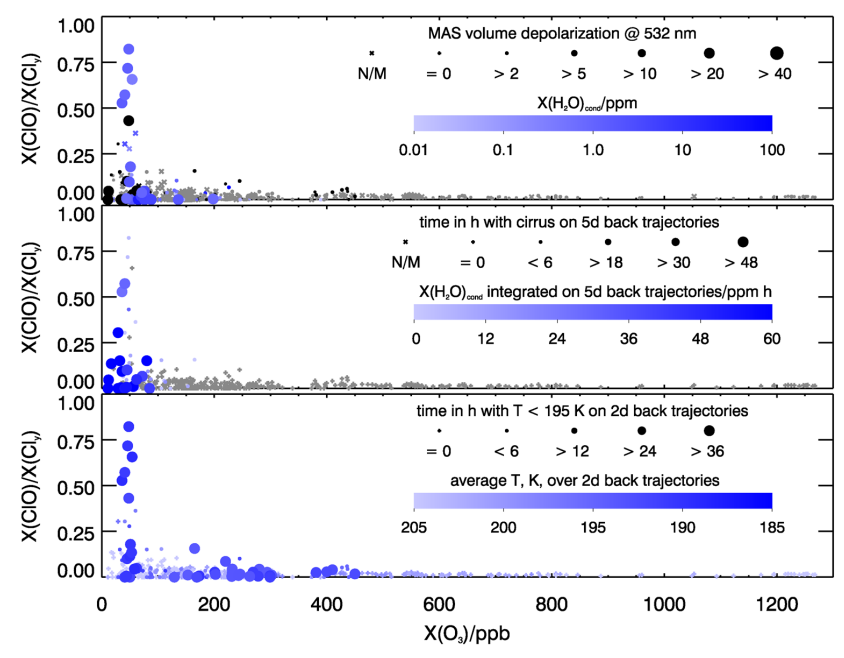

Fig. 5. $\mathrm{ClO} / \mathrm{Cl}_{\mathrm{y}}$ ratios as a function of $\mathrm{O}_{3}$ mixing ratio and characterization of the "heterogeneous chemistry potential". Top panel: ice water content (colour code; grey: $\left[\mathrm{H}_{2} \mathrm{O}\right]_{\text {cond }}=0$, black: no data) and volume depolarisation (symbol size; N/M: not measured) as proxies for cirrus particles; middle panel: integrated ice water content (colour code) and time with ice present (symbol size; N/M: not measured) simulated on 5 day back trajectories to estimate the extent of cirrus occurrence preceding the flights; bottom panel: mean ECMWF temperatures for 2 day back trajectories (colour code) and time at $T<195 \mathrm{~K}$ (symbol size). For uncertainties in $X(\mathrm{ClO}) / X\left(\mathrm{Cl}_{\mathrm{y}}\right)$ cf. caption to Fig. 4.

also seems unlikely because sea salt is efficiently removed by convective cloud processing before reaching the TTL (Froyd et al., 2009) and was consequently found to be absent in residual particles from evaporated high altitude subvisible cirrus ice crystals in extensive measurements made during the CR-AVE campaign (Froyd et al., 2010).

For TROCCINOX and SCOUT-O 3 , neither observations (e.g. tracers, water vapour, etc.) nor trajectory calculations support direct transport of boundary layer air to the TTL 
for the probed air masses with elevated $\mathrm{ClO}$ mixing ratios. The fact that observed $\mathrm{ClO}$ mixing ratios were generally higher during SCOUT- $\mathrm{O}_{3}$ - at a site strongly influenced by marine air - than during TROCCINOX (Fig. 3) could of course point to transport from the marine boundary layer, but we deem this unlikely for the reasons described above. A more plausible explanation may be the higher altitude of the tropopause and the observed cirrus clouds and therefore possibly a higher abundance of $\mathrm{Cl}_{\mathrm{y}}$ that can be activated during the SCOUT-O $\mathrm{O}_{3}$ campaign in Darwin. The tropopause was also significantly colder during $\mathrm{SCOUT}_{-} \mathrm{O}_{3}$ than during TROCCINOX (Fig. 2a), resulting in faster heterogeneous processing on background aerosol and more extensive and prolonged cirrus formation during $\mathrm{SCOUT}-\mathrm{O}_{3}$. This conclusion is supported by the CLaMS_CTM simulations.

\section{Case studies - investigation of the $\mathrm{Cl}$ activation mechanism}

Several incidences of strongly enhanced $\mathrm{ClO}$ were observed during two $\mathrm{SCOUT}^{-} \mathrm{O}_{3}$ flights on 19 and 30 November 2005, which we examine in more detail in the following. Figures 6 and 7 show observations of $\mathrm{ClO}, \mathrm{O}_{3}, \mathrm{NO}_{\mathrm{y}}$ and $\mathrm{NO}, \mathrm{H}_{2} \mathrm{O}$ (gas phase and total), particle number densities, temperature and solar zenith angle as well as ice water content predicted by CLaMS simulations along the flight path and along 5-day backtrajectories preceding the flight. For 19 November, the HALOX NO-addition-cycle integration was carried out with a variable time resolution such that time resolution is maximised while still obtaining a sufficient signal-to-noise ratio. For the most prominent event of potential cirrus activation (cf. below), mean and standard deviation of all points inside the grey shaded area are also shown. Between 06:00 and 07:00 UTC, when the aircraft carried out a rapid succession of short ascents and descents, the frequency of variations in pressure and temperature was higher than the averaging time scales needed to obtain data at an adequate signal-to-noise ratio. On 30 November, longer averaging periods were necessary due to low detector sensitivity.

In many cases, the enhanced $\mathrm{ClO}$ is clearly associated with cirrus clouds, i.e. elevated $\mathrm{ClO}$ occurs with low temperature and the presence of ice water. The latter is deduced from either FISH total water mixing ratios exceeding gas phase water vapour and/or the saturation over ice (unfortunately, no FLASH data are available for 30 November 2005), or from the presence of large particles detected by the FSSP instrument, or both. From the CLaMS simulations, the presence of ice seems likely also for the point with $\sim 22 \mathrm{ppt} \mathrm{ClO}$ at the end of the ascent on 19 November. The $\mathrm{ClO}$ mixing ratios around $10 \mathrm{ppt}$ observed near the end of this flight not associated with low temperatures and ice originate from stratospheric air identified by the higher ozone levels measured by FOZAN (cf. also Figs. 3 and 4). The distribution of water vapour around the flight track - estimated using

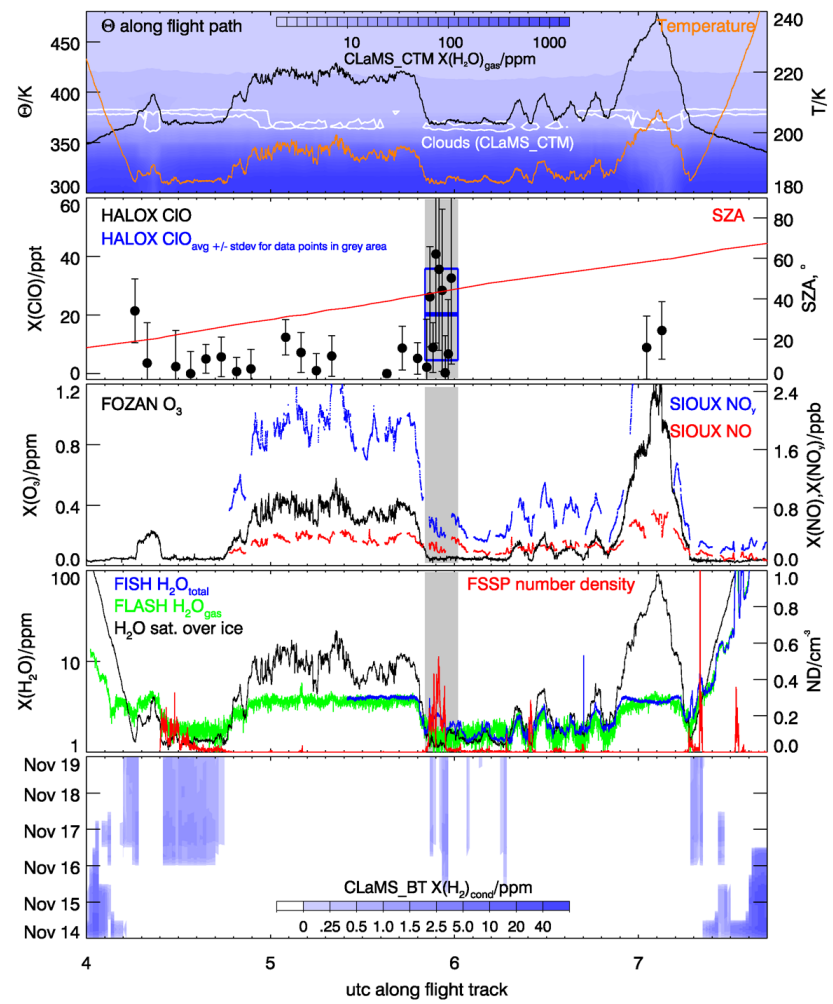

Fig. 6. Observations made during the $\mathrm{SCOUT}_{-} \mathrm{O}_{3}$ flight on 19 November 2005 from Darwin (see text for details). Also shown in the top panel are CLaMS_CTM simulations of $X\left(\mathrm{H}_{2} \mathrm{O}\right)$ around the Geophysica flight track with white contours indicating the predicted occurrence of cirrus clouds. The bottom panel shows CLaMS $X\left(\mathrm{H}_{2} \mathrm{O}\right)_{\text {cond }}$ along 5-day backtrajectories ending on the flight track.

CLaMS_CTM and shown in the top panel - suggests highest $\mathrm{ClO}$ levels near the top of cirrus clouds. For 30 November (Fig. 7), the observations of elevated $\mathrm{ClO}$ are not necessarily found near the top of the cirrus layer, at least according to the CLaMS simulations. Of the three points marked by the grey shading, simultaneous observations of cirrus particles (FSSP and FISH) were only made for the first one. For the second point, an association with cirrus occurrence is uncertain, while the third observation of elevated $\mathrm{ClO}$ at the beginning of the decent coincides with the aircraft passing through a cirrus layer. Interestingly, the observations on 30 November were made in darkness $\left(\mathrm{SZA}>100^{\circ}\right)$, when significant amounts of $\mathrm{ClO}$ are not normally expected. This will be discussed in detail below.

Both flights were investigated in detail using the CLaMS_BT chemistry simulation along back trajectories described in Sect. 2.3. The purpose of these simulations is to understand the observed heterogeneous chlorine activation in a qualitative sense and to investigate possible mechanisms. Clearly, the CLaMS_BT simulations are not expected to quantitatively reproduce all observations made during the flight, because of the uncertainties in the ECMWF 


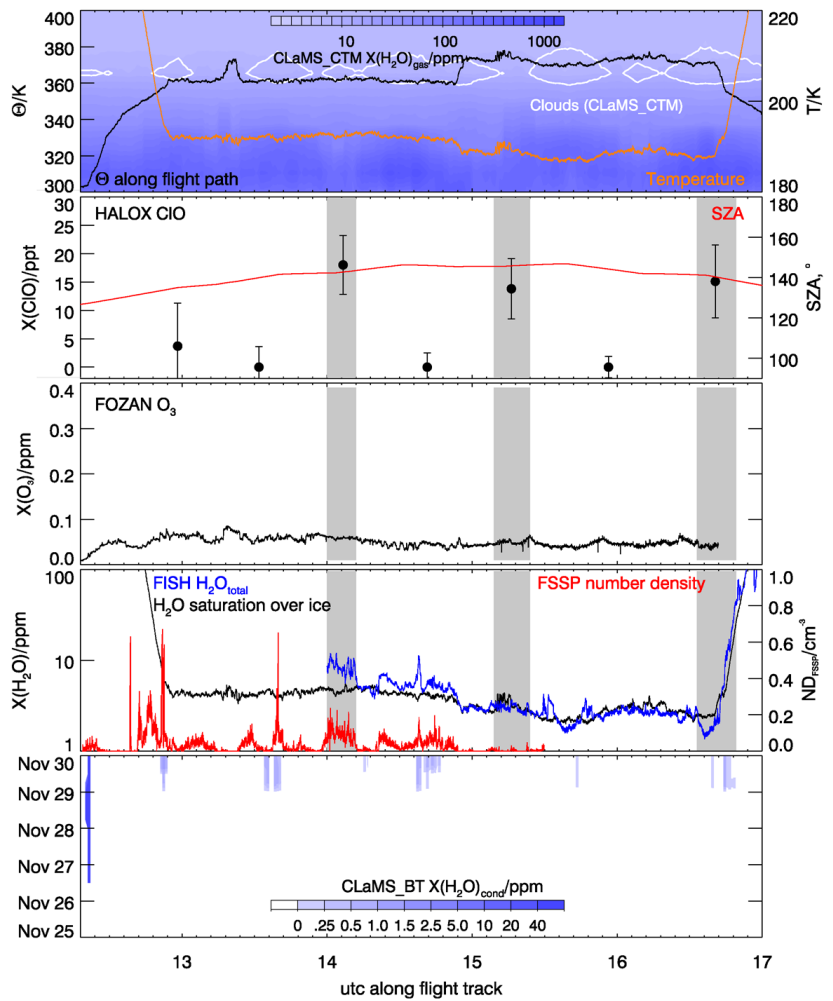

Fig. 7. As Fig. 6 but for the flight on 30 November 2005.

wind fields and more importantly the chemical initialisation. Moreover, processes such as mixing of air masses and sedimentation of ice-particles from higher altitudes are not represented in the model.

Figure 8 shows the simulation results for the flight on 19 November 2005 along one chosen back-trajectory for a time window where high chlorine activation was observed by HALOX. Using the observed mixing ratios of ozone, $\mathrm{NO}_{\mathrm{y}}$, and $\mathrm{H}_{2} \mathrm{O}$, the simulation did not reproduce the observed $\mathrm{ClO}$ mixing ratios. However, the simulation indeed shows the observed almost complete chlorine activation in sensitivity studies run with higher $\mathrm{Br}_{\mathrm{y}}$ and/or $\mathrm{O}_{3}$ mixing ratios (Fig. 8). For the run with $200 \mathrm{ppb} \mathrm{O}_{3}$ and $1 \mathrm{ppt} \mathrm{Br}_{\mathrm{y}}$ (green) CLaMS_BT predicts $\mathrm{ClO}$ to be present in significant amounts during night-time. This is also the case for the 30 November simulation shown in Fig. 9. Here, the observations were actually made in darkness and confirm the model results in this respect. To understand this surprising result, one needs to take a closer look at the night-time reservoir species and the respective rates of $\mathrm{ClO}$ conversion. Both the nature of the night-time reservoir and the conversion rate depend on the chemical conditions, in particular the amounts of $\mathrm{NO}_{\mathrm{x}}$ and $\mathrm{BrO}$ present. When $\mathrm{NO}_{\mathrm{x}}$ is available (with mixing ratios roughly $>15 \mathrm{ppt}$ ), $\mathrm{ClO}$ reacts with $\mathrm{NO}_{2}$ to form $\mathrm{ClONO}_{2}$ (e.g., between 2 and 4 days prior to the observations, the amount of $\mathrm{ClONO}_{2}$ produced in the simulations essentially matches the difference between daytime

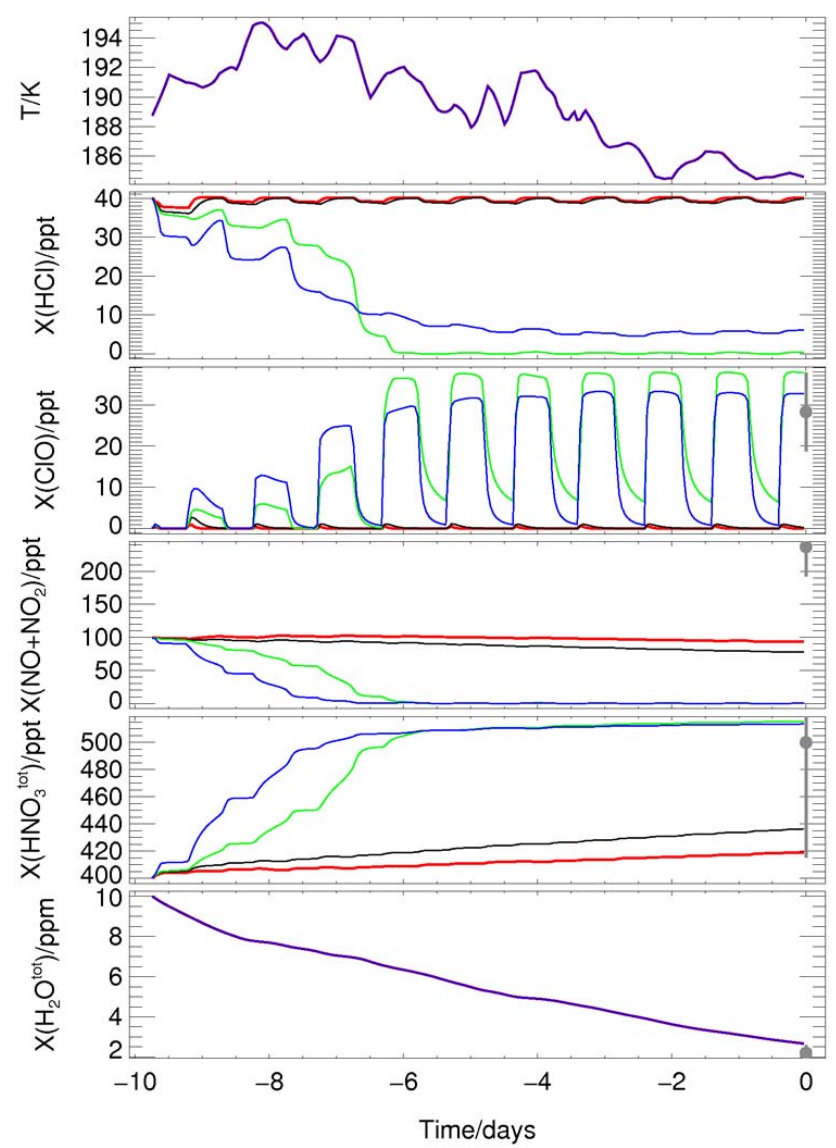

Fig. 8. CLaMS_BT simulation results for the flight on 19 November 2005 for various parameters along a chosen back-trajectory ending on the flight path at 05:51 UTC, i.e. in the time window where chlorine activation was observed by HALOX for different initialisations: Red: 1 ppt $\mathrm{Br}_{\mathrm{y}} / 50 \mathrm{ppb} \mathrm{O}$; black: 1 ppt $\mathrm{Br}_{\mathrm{y}} / 125 \mathrm{ppb} \mathrm{O}_{3}$; green: 1 ppt $\mathrm{Br}_{\mathrm{y}} / 200$ ppb $\mathrm{O}_{3}$; blue: 5 ppt $\mathrm{Br}_{\mathrm{y}} / 125 \mathrm{ppb} \mathrm{O}_{3}$. Corresponding observations at the trajectory endpoints are shown in grey. The observed $x\left(\mathrm{O}_{3}\right)$ was $\sim 60 \mathrm{ppb}$.

and nighttime $\mathrm{NO}_{\mathrm{x}}$ and coincides with the drop in $\mathrm{ClO}$, both shown by the blue and green lines in Fig. 9). If particles are present, this can heterogeneously convert to $\mathrm{Cl}_{2}$ that quickly returns to $\mathrm{ClO}$ after sunrise. If $\mathrm{NO}_{\mathrm{x}}$ levels drop to a few ppt or less, this pathway becomes too inefficient to remove $\mathrm{ClO}$. $\mathrm{OClO}$ and $\mathrm{BrCl}$ are formed at reasonable rates if sufficient $\mathrm{BrO}$ is present. This is the case in the simulations with prescribed $\mathrm{Br}_{\mathrm{y}}$ of 5 ppt (blue line in Figs. 8 and 9, cf. below), while the $1 \mathrm{ppt}$ assumed in the other model runs is not sufficient. If neither $\mathrm{NO}_{2}$ nor $\mathrm{BrO}$ are present, the only significant loss of $\mathrm{ClO}$ at night occurs via the $\mathrm{ClO}$ self reaction $\mathrm{ClO}+\mathrm{ClO}+\mathrm{M} \rightarrow \mathrm{ClOOCl}$. However, even though the rate constant $k_{\mathrm{f}}$ of this dimer formation reaction is fast at low temperatures, the reaction proceeds much slower in the tropical UTLS than for example in the activated polar vortices, which is due to the quadratic dependence of the 


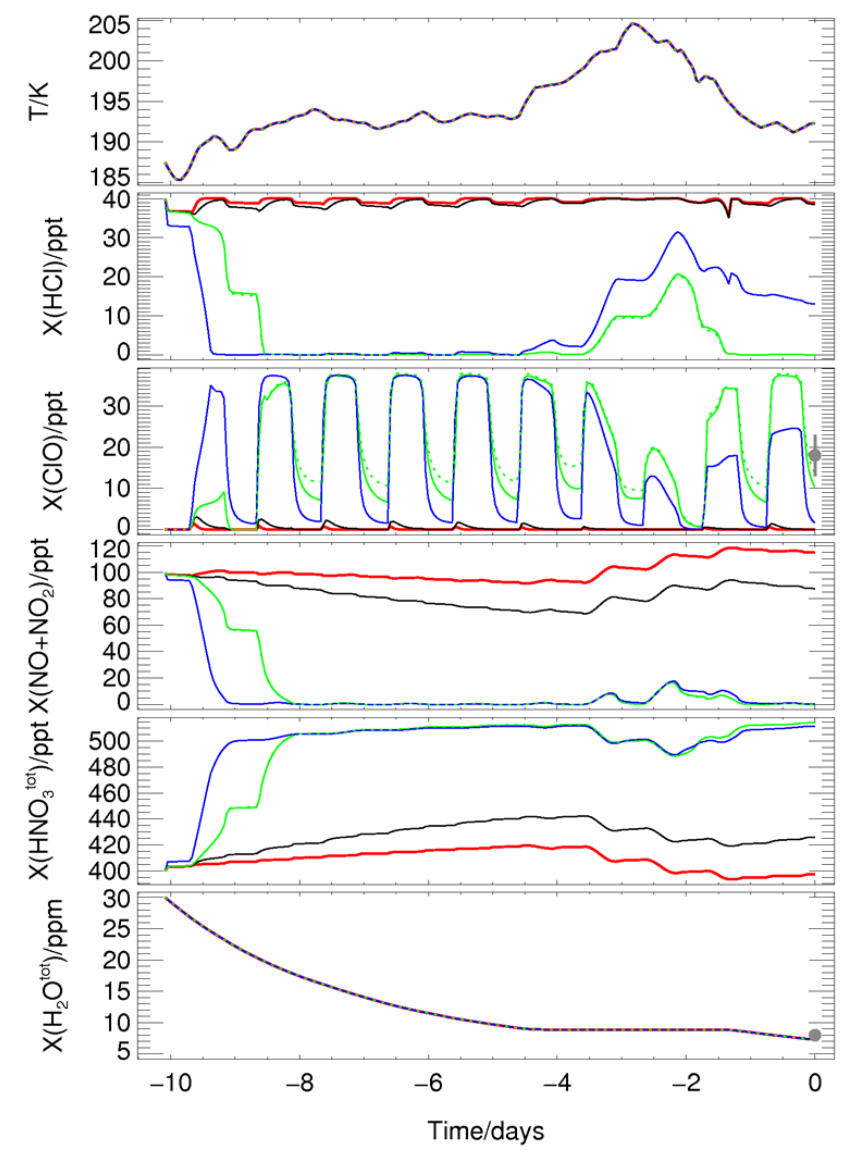

Fig. 9. As Fig. 8 but for the flight on 30 November 2005 with the trajectory ending on the flight path at 14:06 UTC. The dotted lines show simulations with different rate constants for the $\mathrm{ClO} / \mathrm{ClOOCl}$ reaction (see text for details). The observed $x\left(\mathrm{O}_{3}\right)$ was $\sim 60 \mathrm{ppb}$.

reaction rate on the $\mathrm{ClO}$ concentration. For the conditions found on 19 and 30 November, the lifetime of $\mathrm{ClO}$ with respect to dimer formation is too long for complete conversion overnight. This seems to be confirmed by the observed $\mathrm{ClO}$ mixing ratios on 30 November that are even higher than the simulated ones. However, this difference is not surprising given the uncertainties in the measurements, in the amount of $\mathrm{Cl}_{\mathrm{y}}$ with which the model is initialized, and in the rate constants governing the $\mathrm{ClO} / \mathrm{ClOOCl}$ partitioning. The latter is shown by the dotted lines in Fig. 9, where a combination of $k_{\mathrm{f}}$ according to Nickolaisen et al. (1994) and a ClO/ClOOCl equilibrium constant according to Plenge et al. (2005) is used that has been shown by von Hobe et al. (2007) to more realistically reproduce $\mathrm{ClO}$ and $\mathrm{ClOOCl}$ mixing ratios made in the Arctic.

The mechanism of chlorine activation implemented in CLaMS (both CLaMS_ST and CLaMS_BT) is illustrated in Fig. 10. In the presence of ice surfaces and sunlight, chlorine activation is possible by the following reaction chains

$$
\begin{array}{rll}
\mathrm{ClO}+\mathrm{NO}_{2} & \rightarrow \mathrm{ClONO}_{2} & (\mathrm{R} 5) \\
\mathrm{HCl}+\mathrm{ClONO}_{2} & \rightarrow \mathrm{Cl}_{2}+\mathrm{HNO}_{3} & \text { (R1, het.) } \\
\mathrm{Cl}_{2}+h v & \rightarrow 2 \mathrm{Cl} & \text { (R6) } \\
2 \times \quad \mathrm{Cl}+\mathrm{O}_{3} & \rightarrow \mathrm{ClO}+\mathrm{O}_{2} & \text { (R7) } \\
\hline \mathrm{Net}: \mathrm{HCl}+\mathrm{NO}_{2}+2 \mathrm{O}_{3} & \rightarrow \mathrm{ClO}+\mathrm{HNO}_{3}+2 \mathrm{O}_{2} & \text { (chain 1) } \\
& & \\
& & \\
\mathrm{ClO}+\mathrm{HO}_{2} & \rightarrow \mathrm{HOCl}+\mathrm{O}_{2} & (\mathrm{R} 8) \\
\mathrm{HCl}+\mathrm{HOCl} & \rightarrow \mathrm{Cl}_{2}+\mathrm{H}_{2} \mathrm{O} & \text { (R2, het.) } \\
\mathrm{Cl}+h v & \rightarrow 2 \mathrm{Cl} & \text { (R6) } \\
2 \times \mathrm{Cl}+\mathrm{O}_{3} & \rightarrow \mathrm{ClO}+\mathrm{O}_{2} & \text { (R7) } \\
\hline \mathrm{Net}: \mathrm{HCl}+\mathrm{HO}_{2}+2 \mathrm{O}_{3} & \rightarrow \mathrm{ClO}+\mathrm{H}_{2} \mathrm{O}+3 \mathrm{O}_{2} & \text { (chain 2) }
\end{array}
$$

and

\begin{tabular}{rll}
$\mathrm{ClO}+\mathrm{NO}_{2}$ & $\rightarrow \mathrm{ClONO}{ }_{2}$ & (R5) \\
$\mathrm{H}_{2} \mathrm{O}+\mathrm{ClONO} \mathrm{ClN}_{2}$ & $\rightarrow \mathrm{HOCl}+\mathrm{HNO}_{3}$ & (R3, het.) \\
$\mathrm{HCl}+\mathrm{HOCl}$ & $\rightarrow \mathrm{Cl}_{2}+\mathrm{H}_{2} \mathrm{O}$ & (R2, het.) \\
$\mathrm{Cl}_{2}+h v$ & $\rightarrow 2 \mathrm{Cl}$ & (R6) \\
$2 \times \quad \mathrm{Cl}+\mathrm{O}_{3}$ & $\rightarrow \mathrm{ClO}+\mathrm{O}_{2}$ & (R7) \\
\hline Net: $\mathrm{HCl}+\mathrm{NO}_{2}+2 \mathrm{O}_{3}$ & $\rightarrow \mathrm{ClO}+\mathrm{HNO}_{3}+2 \mathrm{O}_{2}$ & (chain 3)
\end{tabular}

Detailed investigations on the reaction rates of all modelled chemical reactions were performed in order to assess the relative importance of these individual reaction chains in the simulations under various conditions. Although all these chains start with a deactivation reaction, two chlorine reservoir molecules are activated by the subsequent heterogeneous reaction, resulting in a net chlorine activation (Müller et al., 1994). At the same time as they activate chlorine, chains 1 and 3 remove $\mathrm{NO}_{\mathrm{x}}$ from the gas phase into the particle phase as $\mathrm{HNO}_{3}$.

These reactions are counteracted by the chlorine deactivation reaction

$\mathrm{Cl}+\mathrm{CH}_{4} \rightarrow \mathrm{HCl}+\mathrm{CH}_{3}$.

The net chlorine activation through chains $1-3$ can only take place if the overall activation rate is faster than the chlorine deactivation via Reaction (R9). The simulations show that once low $\mathrm{NO}_{\mathrm{x}}$ levels are reached (by removal through chains 1 and 3), chlorine partitioning suddenly switches from low to almost complete activation. The reason for this behaviour will be explained below. The sensitivity studies show that the occurrence of this threshold is especially sensitive to $\mathrm{Br}_{\mathrm{y}}$ and $\mathrm{O}_{3}$ levels.

During daytime, when $\mathrm{ClO}$ is present, Reaction (R5) is slow due to most $\mathrm{NO}_{\mathrm{x}}$ being present in the form of NO. To understand the dependencies of chlorine activation on $x\left(\mathrm{Br}_{\mathrm{y}}\right)$ and $x\left(\mathrm{O}_{3}\right)$, the ratios $x(\mathrm{Cl}) / x(\mathrm{ClO})$ and $x\left(\mathrm{NO}_{2}\right) / x(\mathrm{NO})$ are critical. Under tropical daytime conditions in the TTL, $x(\mathrm{Cl}) / x(\mathrm{ClO})$ is determined by Reactions ( $\mathrm{R} 7)$ and 


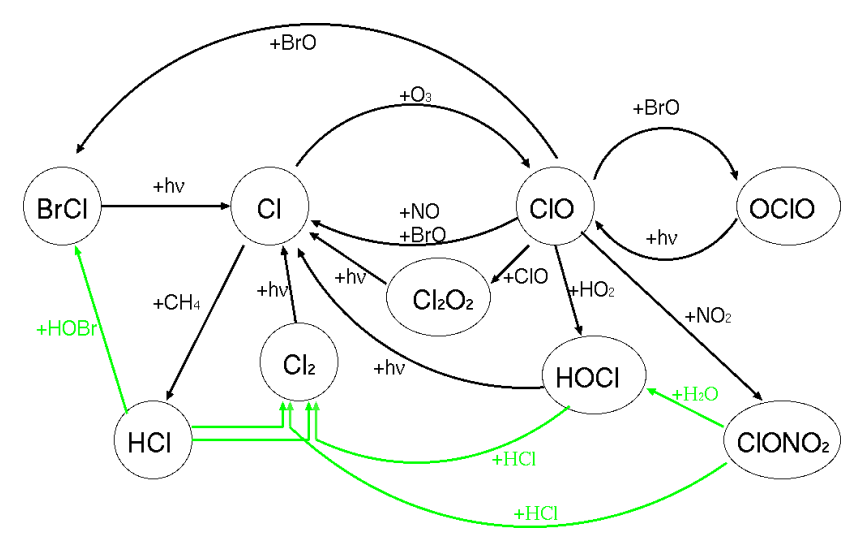

Fig. 10. Schematic of the chemical reaction system governing chlorine partitioning in ClaMS. Green arrows denote heterogeneous reactions.

$\mathrm{ClO}+\mathrm{NO} \rightarrow \mathrm{Cl}+\mathrm{NO}_{2}$.

and can be approximated by

$\frac{x(\mathrm{Cl})}{x(\mathrm{ClO})}=\frac{c(\mathrm{Cl})}{c(\mathrm{ClO})}=\frac{k_{10} c(\mathrm{NO})}{k_{7} c\left(\mathrm{O}_{3}\right)}$

assuming photochemical steady state.

Similarly, the $x\left(\mathrm{NO}_{2}\right) / x(\mathrm{NO})$ ratio is determined by (R10),

$\mathrm{BrO}+\mathrm{NO} \rightarrow \mathrm{Br}+\mathrm{NO}_{2}$

$\mathrm{O}_{3}+\mathrm{NO} \rightarrow \mathrm{O}_{2}+\mathrm{NO}_{2}$,

and

$\mathrm{NO}_{2}+h v \rightarrow \mathrm{NO}+\mathrm{O}$

giving

$\frac{x\left(\mathrm{NO}_{2}\right)}{x(\mathrm{NO})}=\frac{c\left(\mathrm{NO}_{2}\right)}{c(\mathrm{NO})}=\frac{k_{10} c(\mathrm{ClO})+k_{11} c(\mathrm{BrO})+k_{12} c\left(\mathrm{O}_{3}\right)}{J_{13}}$

The simulations show that chain 1 is most important in the case of low chlorine activation. The chlorine activation rate $R_{\text {act_1 }}$ through chain 1 is given by

$R_{\text {Act_1 }}=k_{5} c(\mathrm{ClO}) c\left(\mathrm{NO}_{2}\right)$

which, using Eq. (2), becomes

$R_{\text {Act_ } 1}=k_{5} c(\mathrm{ClO}) c(\mathrm{NO}) \frac{k_{10} c(\mathrm{ClO})+k_{11} c(\mathrm{BrO})+k_{12} c\left(\mathrm{O}_{3}\right)}{J_{13}}$.

The deactivation rate $R_{\text {Deact_9 }}$ through Reaction (R1) is given by

$R_{\text {Deact }-9}=k_{9} c(\mathrm{Cl}) c\left(\mathrm{CH}_{4}\right)$

which, using Eq. (1), becomes

$R_{\text {Deact_9 }}=\frac{k_{9} k_{10} c(\mathrm{NO}) c(\mathrm{ClO}) c\left(\mathrm{CH}_{4}\right)}{k_{7} c\left(\mathrm{O}_{3}\right)}$
A sufficient condition for chlorine activation in the presence of ice surfaces is given if the chlorine activation rate exceeds the deactivation rate:

$\frac{R_{\text {Act_1 }}}{R_{\text {Deact_9 }}}=\frac{k_{5} k_{7} c\left(\mathrm{O}_{3}\right)}{k_{9} k_{10} J_{13}} \frac{k_{10} c(\mathrm{ClO})+k_{11} c(\mathrm{BrO})+k_{12} c\left(\mathrm{O}_{3}\right)}{c\left(\mathrm{CH}_{4}\right)}>1$

The simulations show that $\mathrm{NO}_{\mathrm{x}}$ is converted to $\mathrm{HNO}_{3}$ by chains 1 and 3 (with chain 1 dominating). If very low $\mathrm{NO}_{\mathrm{x}}$ mixing ratios are reached, chains 1 and 3 do not work anymore and further chlorine activation can only occur via chain 2 .

The condition formulated above (Eq. 7) is independent of $\mathrm{NO}_{\mathrm{x}}$. Simulations demonstrate that in the case that chlorine is already activated, the chlorine activation chains keep working, even if $\mathrm{NO}_{\mathrm{x}}$ is added. However, in this case, $\mathrm{NO}_{\mathrm{x}}$ is converted to $\mathrm{HNO}_{3}$ at a rate of about $150 \mathrm{ppt} /$ day through chain 1.

The dependence of $R_{\text {Act_1 }} / R_{\text {Deact_9 }}$ (Eq. 7) on ClO itself is the main reason for the threshold-like behaviour of chlorine activation. If some chlorine is activated and is in the form of $\mathrm{ClO}$, the effective activation rate increases. This causes a hysteresis-like behaviour in chlorine activation: under otherwise identical conditions, air masses with activated chlorine may stay activated whereas air masses without chlorine activation may not be activated at all. In the case of full activation an almost complete removal of $\mathrm{NO}_{\mathrm{x}}$ is simulated.

Although chlorine activation is not simulated using the observed mixing ratios of $\mathrm{O}_{3}, \mathrm{BrO}$ and $\mathrm{NO}_{\mathrm{x}}$, it has been shown that the point at which the system switches to chlorine activation sensitively depends on a number of factors. Possible uncertainties are present in the simulation e.g. the reaction rates or possible omitted chemical reactions, and temperatures along the back-trajectory. A Gaussian error propagation of Eq. (7) with respect to uncertainties of the individual rate constants given in Sander et al. (2006) at $200 \mathrm{~K}$ yields an uncertainty of about a factor of 3 for $R_{\text {Act_1 }} / R_{\text {Deact_9 }}$ (this does not yet include the uncertainty of the photolysis rate or the uncertainty of any of the chemical species concentrations). Further, there are indications that the formation of $\mathrm{HOCl}$ from $\mathrm{ClO}+\mathrm{HO}_{2}$ may be faster than recommended (Kovalenko et al., 2007; Stimpfle et al., 1979; von Clarmann et al., 2008). If these indications were true the $\mathrm{Cl}$ activation would be even faster.

To illustrate the complex sensitivity of chlorine activation to various mixing ratios and rate constants, we plotted in Fig. 11 the $\mathrm{ClO}$ mixing ratio on the final day of the trajectory that ends on the observed point with high chlorine activation for different initial ozone mixing ratios. The red symbols show results for the $1 \mathrm{ppt} \mathrm{Br}_{\mathrm{y}}$ and the standard set of chemical reactions. A full $\mathrm{Cl}$-activation is found for ozone mixing ratios above a threshold of about $185 \mathrm{ppb}$. The precise location of this threshold depends on model parameters.

If for the reaction $\left(\mathrm{ClO}+\mathrm{HO}_{2}\right)$ a faster rate coefficient is assumed as suggested by (Kovalenko et al., 2007; Stimpfle et al., 1979; von Clarmann et al., 2008), the threshold for full 


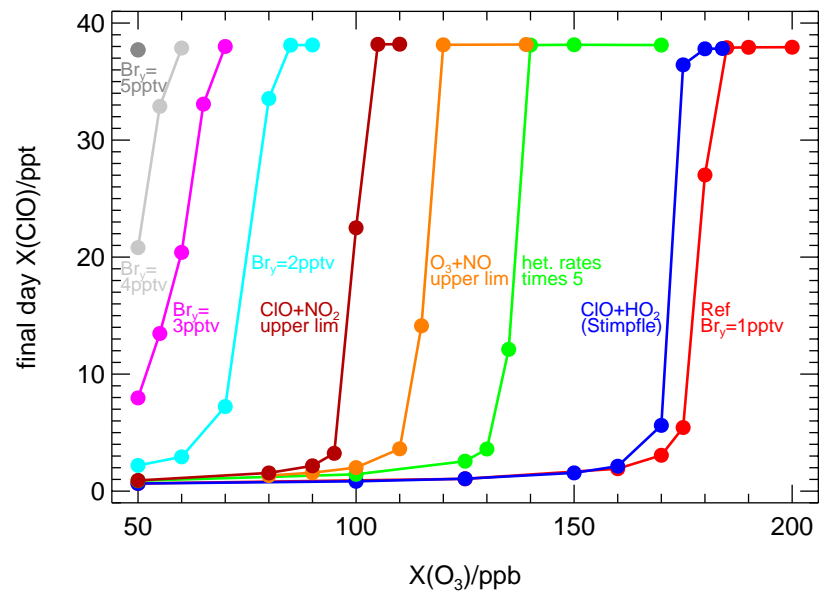

Fig. 11. Sensitivity of final day $\mathrm{ClO}$ in the CLaMS_BT simulation results for the flight on 19 November 2005 (Fig. 8) to ozone mixing ratio for various input parameterisations as described in detail in the text. The changes made to the reference parameterisation (red) are indicated in the graph and are cumulative from right to left.

chlorine activation is found at slightly lower ozone mixing ratios (blue symbols in Fig. 11). In addition, there are assumptions in this simulation that also introduce uncertainty in the heterogeneous reaction rates. A sensitivity study was performed using an increase of all heterogeneous reaction rates by a factor of 5 (green symbols). This would correspond to using the lower climatological limit of ice particle radius of about $2 \mu \mathrm{m}$ (Gensch et al., 2008; Krämer et al., 2009; Möhler et al., 2005). The uncertainty of gasphase reaction rate coefficients at temperatures below $190 \mathrm{~K}$ is also significant. The orange symbols show simulations in which the reaction rate coefficient of the reaction $\mathrm{O}_{3}+\mathrm{NO}$ is changed to the upper error limit of the recommended value. The brown symbols correspond to the upper error limit of the recommended value for the reaction $\left(\mathrm{ClO}+\mathrm{NO}_{2}\right)$. The position of the threshold also depends on the amount of available $\mathrm{Br}_{\mathrm{y}}$. The remaining symbols (light blue, pink, light grey, dark grey) correspond to assumptions of larger $\mathrm{Br}_{\mathrm{y}}$ mixing ratios of 2, 3, 4, and $5 \mathrm{ppt}$, respectively. A combination of all changes with the assumption of $5 \mathrm{ppt} \mathrm{Br}$ yould result in full chlorine activation at $50 \mathrm{ppb} \mathrm{O}_{3}$.

The amount of $\mathrm{Br}_{\mathrm{y}}$ from VSLS entering the stratosphere is subject to debate. A range of 3-8 ppt is given in WMO (2006). A comprehensive inventory of bromine containing VSLS from balloon-borne measurements (Laube et al., 2008) supports the lower end of this given range, while Salawitch et al. (2010) argue for a contribution of up to $10 \mathrm{ppt}$. In any case, VSLS bromine would not be expected to be completely converted to inorganic forms in the more tropospheric air masses encountered here, and neither the HALOX BrO measurements (always $<4$ ppt detection limit) nor earlier observations of inorganic bromine in the tropical upper troposphere and UTLS (Dorf et al., 2008) warrant mixing ratios above 5 ppt. Finally, the blue lines in Figs. 8 and 9 show that 5 ppt $\mathrm{Br}_{\mathrm{y}}$ are sufficient to remove most of the $\mathrm{ClO}$ present rapidly after nightfall, so $5 \mathrm{ppt} \mathrm{Br}_{\mathrm{y}}$ would be inconsistent with the observation of $\mathrm{ClO}$ being present in darkness.

For the combinations of $\mathrm{O}_{3}$ and $\mathrm{Br}_{\mathrm{y}}$ mixing ratios resulting in heterogeneous chlorine activation, the CLaMS_BT simulation yields much lower $\mathrm{NO}_{\mathrm{x}}$ values than observed. This is puzzling, because any $\mathrm{ClO}$ formed will rapidly react with $\mathrm{NO}_{2}$ to form $\mathrm{ClONO}_{2}$. But as long as the ice particles providing the heterogeneous surfaces are there, the deactivation caused by this reaction will not persist. To the contrary, chlorine activation is preserved or even amplified by $\mathrm{ClONO}_{2}$ reacting heterogeneously with $\mathrm{HCl}$ or $\mathrm{H}_{2} \mathrm{O}$ (Fig. 10) until at some point all the $\mathrm{NO}_{\mathrm{x}}$ is removed from the gas phase into $\mathrm{HNO}_{3}$ on the particles by this process (blue and green lines in Figs. 8 and 9). This happens on a time-scale of about 1 day, so the simultaneous observation of high $\mathrm{ClO}$ and $\mathrm{NO}_{\mathrm{x}}$ mixing ratios can be explained if the $\mathrm{NO}_{\mathrm{x}}$ measured by SIOUX was produced or transported within a few hours preceding the flight. A plausible explanation may be in-situ $\mathrm{NO}_{\mathrm{x}}$ production by lightning in Hector and other single cell continental thunderstorms in the measurement area. A sensitivity simulation was carried out, in which $300 \mathrm{ppt}$ of the prevailing $\mathrm{HNO}_{3}$ was artificially reformed into $\mathrm{NO}_{\mathrm{x}}$. It was observed that the $\mathrm{NO}_{\mathrm{x}}$ addition did leave the model in the chlorineactivated state, and the additional $\mathrm{NO}_{\mathrm{x}}$ was reformed back to $\mathrm{HNO}_{3}$ through reaction chains 1 and 3 on a time scale of about one day. Thus, jointly elevated $\mathrm{ClO}$ and $\mathrm{NO}_{\mathrm{x}}$ is plausible if the in-mixing of $\mathrm{NO}_{\mathrm{x}}$-rich air is indeed very recent. Huntrieser et al. (2009) find clear evidence for lightning induced $\mathrm{NO}_{\mathrm{x}}$ by thunderstorm systems on 19 November between 02:00 and 07:00 UTC at lower flight levels observed by the DLR Falcon aircraft. The elevated $\mathrm{NO}_{\mathrm{x}}$ observed by SIOUX on the Geophysica just before 06:00 UTC could be a product of fresh outflow from these systems.

In-mixing of fresh convective outflow would also affect ozone mixing ratios, which on both days were on the order of $50 \mathrm{ppb}$ for the parts of the flights where elevated $\mathrm{ClO}$ was observed, quite in contrast to the $200 \mathrm{ppb}_{3}$ needed to obtain heterogeneous activation in the CLaMS_BT simulations.

\section{Conclusions}

Observations of $\mathrm{ClO}$ in the tropics between 11 and $20 \mathrm{~km}$ altitude were made during two aircraft campaigns in 2005. In general, higher $\mathrm{ClO}$ mixing ratios were found in air masses of stratospheric origin, but incidences of enhanced $\mathrm{ClO}$ of up to $40 \mathrm{ppt}$ in tropospherically dominated air masses were observed during and after cirrus events and/or following periods of relatively low temperatures. Thus there is strong evidence for heterogeneous chlorine activation proceeding in the tropical UTLS on both ice particles and background aerosol at low temperature, although our results do not provide sufficient evidence to assess the relative importance of 
the two. As demonstrated by CLaMS_ST and CLaMS_CTM simulations, the amount of active chlorine that can be produced by heterogeneous activation, and consequently $\mathrm{ClO}$ mixing ratios in the tropical UTLS, depend most strongly on the availability of $\mathrm{Cl}_{\mathrm{y}}$ and on the persistence of temperatures below $\approx 195 \mathrm{~K}$ and/or the life-time of the cirrus clouds. With the CLaMS_BT simulations for the case studies we could demonstrate that an almost complete chlorine activation near the tropopause is possible but depends on many factors. Because of competing activation and deactivation chains, different $\mathrm{Cl}$ activation may be found in similar air masses. With the known chemical mechanisms and rate constants, the conditions under which the CLaMS model predicts complete activation is most sensitive to $\mathrm{O}_{3}$ and $\mathrm{Br}_{\mathrm{y}}$ concentrations, with uncertainties in individual reaction rate constants leading to a significant uncertainty in the threshold condition for the domination of the chlorine activation chain.

Clearly, the model parameters used in the CLaMS model runs where almost complete activation was simulated do not correspond closely to observations, in particular with respect to observed $\mathrm{O}_{3}$ and $\mathrm{NO}_{\mathrm{x}}$ levels, suggesting that the understanding and, consequently, model implementation of the relevant chemical processes in the TTL is yet incomplete. Part of the discrepancies may be explained by uncertainties in rate constants and $\mathrm{Br}_{\mathrm{y}}$ levels, and/or mixing processes within less than one day prior to the observations.

Acknowledgements. The authors thank MDB for their support of the Geophysica operations during the field campaigns and for the supply of avionic data. For organisation of and support during field campaigns, we are also grateful to the airport teams in Aracatuba and Darwin, and to the TROCCINOX and SCOUT-O 3 coordinating and mission planning teams. The manuscript was improved a great deal though constructive reviews by R. Salawitch and two anonymous reviewers, and through valuable comments and suggestions by D. Toohey, K. Pfeilsticker and S. Grießbach. We thank C. M. Volk for an insightful discussion on the suitability of and caveats associated with different tracers to estimate $\mathrm{Cl}_{\mathrm{y}}$ in the tropical UTLS and lower stratosphere, which was extremely helpful in assessing and describing the uncertainties of the approach used. We further thank ECMWF for meteorological analyses. The TROCCINOX project was funded by the EU under the grant number EVK2-2001-00087. SCOUT-O 3 was funded by the EU under the grant number 505390-GOCE-CT-2004. The Atmospheric Chemistry Experiment (ACE), also known as SCISAT, is a Canadian-led mission mainly supported by the Canadian Space Agency.

Edited by: J. Kaiser

\section{References}

Avallone, L. M., Toohey, D. W., Brune, W. H., Salawitch, R. J., Dessler, A. E., and Anderson, J. G.: Balloon-Borne in-Situ Measurements of $\mathrm{ClO}$ and Ozone - Implications For Heterogeneous Chemistry and Midlatitude Ozone Loss, Geophys. Res. Lett., 20, 1795-1798, 1993.

Bernath, P. F., McElroy, C. T., Abrams, M. C., Boone, C. D., Butler, M., Camy-Peyret, C., Carleer, M., Clerbaux, C., Coheur, P.-F., Colin, R., DeCola, P., DeMazière, M., Drummond, J. R., Dufour, D., Evans, W. F. J., Fast, H., Fussen, D., Gilbert, K., Jennings, D. E., Llewellyn, E. J., Lowe, R. P., Mahieu, E., McConnell, J. C., McHugh, M., McLeod, S. D., Michaud, R., Midwinter, C., Nassar, R., Nichitiu, F., Nowlan, C., Rinsland, C. P., Rochon, Y. J., Rowlands, N., Semeniuk, K., Simon, P., Skelton, R., Sloan, J. J., Soucy, M.-A., Strong, K., Tremblay, P., Turnbull, D., Walker, K. A., Walkty, I., Wardle, D. A., Wehrle, V., Zander, R., and Zou, J.: Atmospheric Chemistry Experiment (ACE): Mission overview, Geophys. Res. Lett., 32, L15S01, doi:10.1029/2005GL022386, 2005.

Borrmann, S., Solomon, S., Dye, J. E., and Luo, B. P.: The potential of cirrus clouds for heterogeneous chlorine activation, Geophys Res. Lett., 23, 2133-2136, 1996.

Borrmann, S., Solomon, S., Avallone, L., Toohey, D., and Baumgardner, D.: On the occurrence of $\mathrm{ClO}$ in cirrus clouds and volcanic aerosol in the tropopause region, Geophys. Res. Lett., 24, 2011-2014, 1997.

Bregman, B., Wang, P. H., and Lelieveld, J.: Chemical ozone loss in the tropopause region on 15 subvisible ice clouds, calculated with a chemistry-transport model, J. Geophys. Res., 107, 4032, doi:10.1029/2001JD000761, 2002.

Brune, W. H., Anderson, J. G., and Chan, K. R.: Insitu Observations of $\mathrm{ClO}$ in the Antarctic - ER-2 Aircraft Results From 54-Degrees-S to 72-Degrees-S Latitude, J. Geophys. Res., 94, 16649-16663, 1989.

Brunner, D., Siegmund, P., May, P. T., Chappel, L., Schiller, C., Müller, R., Peter, T., Fueglistaler, S., MacKenzie, A. R., Fix, A., Schlager, H., Allen, G., Fjaeraa, A. M., Streibel, M., and Harris, N. R. P.: The SCOUT-O3 Darwin Aircraft Campaign: rationale and meteorology, Atmos. Chem. Phys., 9, 93-117, doi:10.5194/acp-9-93-2009, 2009.

Buontempo, C., Cairo, F., Di Donfrancesco, G., Morbidini, R., Viterbini, M., and Adriani, A.: Optical measurements of atmospheric particles from airborne platforms: in situ and remote sensing instruments for balloons and aircrafts, Ann. Geophys., 49, 57-65, 2006,

http://www.ann-geophys.net/49/57/2006/.

Crutzen, P. J. and Lawrence, M. G.: The impact of precipitation scavenging on the transport of trace gases: A 3-dimensional model sensitivity study, J. Atmos. Chem., 37(1), 81-112, 2000.

de Reus, M., Borrmann, S., Bansemer, A., Heymsfield, A. J., Weigel, R., Schiller, C., Mitev, V., Frey, W., Kunkel, D., Krten, A., Curtius, J., Sitnikov, N. M., Ulanovsky, A., and Ravegnani, F.: Evidence for ice particles in the tropical stratosphere from in-situ measurements, Atmos. Chem. Phys., 9, 6775-6792, doi:10.5194/acp-9-6775-2009, 2009.

Dorf, M., Butler, J. H., Butz, A., Camy-Peyret, C., Chipperfield, M. P., Kritten, L., Montzka, S. A., Simmes, B., Weidner, F., and Pfeilsticker, K.: Long-term observations of stratospheric bromine reveal slow down in growth, Geophys. Res. Lett., 33, 
L24803, doi:10.1029/2005GL025466, 2006.

Dorf, M., Butz, A., Camy-Peyret, C., Chipperfield, M. P., Kritten, L., and Pfeilsticker, K.: Bromine in the tropical troposphere and stratosphere as derived from balloon-borne $\mathrm{BrO}$ observations, Atmos. Chem. Phys., 8, 7265-7271, doi:10.5194/acp-8-72652008, 2008.

Froyd, K. D., Murphy, D. M., Sanford, T. J., Thomson, D. S., Wilson, J. C., Pfister, L., and Lait, L.: Aerosol composition of the tropical upper troposphere, Atmos. Chem. Phys., 9, 4363-4385, doi:10.5194/acp-9-4363-2009, 2009.

Froyd, K. D., Murphy, D. M., Lawson, P., Baumgardner, D., and Herman, R. L.: Aerosols that form subvisible cirrus at the tropical tropopause, Atmos. Chem. Phys., 10, 209-218, doi:10.5194/acp-10-209-2010, 2010.

Fu, D., Boone, C. D., Bernath, P. F.,Walker, K. A., Nassar, R., Manney, G. L., and McLeod, S. D.: Global phosgene observations from the Atmospheric Chemistry Experiment (ACE) mission, Geophys. Res. Lett., 34, L17815, doi:10.1029/2007GL029942, 2007.

Fusco, A. C. and Salby, M. L.: Interannual variations of total ozone and their relationship to variations of planetary wave activity, J. Climate, 12, 1619-1629, 1999.

Gensch, I. V., Bunz, H., Baumgardner, D. G., Christensen, L. E., Fahey, D. W., Herman, R. L., Popp, P. J., Smith, J. B., Troy, R. F., Webster, C. R., Weinstock, E. M., Wilson, J. C., Peter, T., and Krämer, M.: Supersaturations, microphysics and nitric acid partitioning in a cold cirrus cloud observed during CR-AVE 2006: an observation-modelling intercomparison study, Environ. Res. Lett., 3, 035003, doi:10.1088/1748-9326/3/3/035003, 2008.

Grooß, J. U., Brühl, C., and Peter, T.: Impact of aircraft emissions on tropospheric and stratospheric ozone. Part I: Chemistry and 2-D model results, Atmos. Environ., 32, 3173-3184, 1998.

Grooß, J. U., Günther, G., Konopka, P., Müller, R., McKenna, D. S., Stroh, F., Vogel, B., Engel, A., Muller, M., Hoppel, K., Bevilacqua, R., Richard, E., Webster, C. R., Elkins, J. W., Hurst, D. F., Romashkin, P. A., and Baumgardner, D. G.: Simulation of ozone depletion in spring 2000 with the Chemical Lagrangian Model of the Stratosphere (CLaMS), J. Geophys. Res., 107, 8295, doi:10.1029/2001JD000933, 2002.

Hanson, D. R., Ravishankara, A. R., and Solomon, S.: Heterogeneous Reactions in Sulfuric-Acid Aerosols - a Framework For Model-Calculations, J. Geophys. Res., 99, 3615-3629, 1994.

Hood, L. L. and Soukharev, B. E.: Interannual variations of total ozone at northern midlatitudes correlated with stratospheric EP flux and potential vorticity, J. Atmos. Sci., 62, 3724-3740, 2005.

Huntrieser, H., Schlager, H., Roiger, A., Lichtenstern, M., Schumann, U., Kurz, C., Brunner, D., Schwierz, C., Richter, A., and Stohl, A.: Lightning-produced $\mathrm{NO}_{\mathrm{x}}$ over Brazil during TROCCINOX: airborne measurements in tropical and subtropical thunderstorms and the importance of mesoscale convective systems, Atmos. Chem. Phys., 7, 2987-3013, doi:10.5194/acp-7-29872007, 2007.

Huntrieser, H., Schlager, H., Lichtenstern, M., Roiger, A., Stock, P., Minikin, A., Höller, H., Schmidt, K., Betz, H.-D., Allen, G., Viciani, S., Ulanovsky, A., Ravegnani, F., and Brunner, D.: $\mathrm{NO}_{\mathrm{x}}$ production by lightning in Hector: first airborne measurements during SCOUT-O3/ACTIVE, Atmos. Chem. Phys., 9, 83778412, doi:10.5194/acp-9-8377-2009, 2009.

Keim, E. R., Fahey, D. W., DelNegro, L. A., Woodbridge, E. L.,
Gao, R. S., Wennberg, P. O., Cohen, R. C., Stimpfle, R. M., Kelly, K. K., Hintsa, E. J., Wilson, J. C., Jonsson, H. H., Dye, J. E., Baumgardner, D., Kawa, S. R., Salawitch, R. J., Proffitt, M. H., Loewenstein, M., Podolske, J. R., and Chan, K. R.: Observations of large reductions in the NO/NOy ratio near the mid-latitude tropopause and the role of heterogeneous chemistry, Geophys. Res. Lett., 23, 3223-3226, 1996.

Konopka, P., Steinhorst, H. M., Grooß, J. U., Günther, G., Müller, R., Elkins, J. W., Jost, H. J., Richard, E., Schmidt, U., Toon, G., and McKenna, D. S.: Mixing and ozone loss in the 1999-2000 Arctic vortex: Simulations with the three-dimensional Chemical Lagrangian Model of the Stratosphere (CLaMS), J. Geophys. Res., 109, D02315, doi:10.1029/2003JD003792, 2004.

Konopka, P., Günther, G., Müller, R., dos Santos, F. H. S., Schiller, C., Ravegnani, F., Ulanovsky, A., Schlager, H., Volk, C. M., Viciani, S., Pan, L. L., McKenna, D.-S., and Riese, M.: Contribution of mixing to upward transport across the tropical tropopause layer (TTL), Atmos. Chem. Phys., 7, 3285-3308, doi:10.5194/acp-7-3285-2007, 2007.

Kovalenko, L. J., Jucks, K. W., Salawitch, R. J., Toon, G. C., Blavier, J. F., Johnson, D. G., Kleinbohl, A., Livesey, N. J., Margitan, J. J., Pickett, H. M., Santee, M. L., Sen, B., Stachnik, R. A., and Waters, J. W.: Observed and modeled $\mathrm{HOCl}$ profiles in the midlatitude stratosphere: Implication for ozone loss, Geophys. Res. Lett., 34, L19801, doi:10.1029/2007GL031100, 2007.

Krämer, M., Schiller, C., Afchine, A., Bauer, R., Gensch, I., Mangold, A., Schlicht, S., Spelten, N., Sitnikov, N., Borrmann, S., de Reus, M., and Spichtinger, P.: Ice supersaturations and cirrus cloud crystal numbers, Atmos. Chem. Phys., 9, 3505-3522, doi:10.5194/acp-9-3505-2009, 2009.

Laube, J. C., Engel, A., Bönisch, H., Möbius, T., Worton, D. R., Sturges, W. T., Grunow, K., and Schmidt, U.: Contribution of very short-lived organic substances to stratospheric chlorine and bromine in the tropics - a case study, Atmos. Chem. Phys., 8, 7325-7334, doi:10.5194/acp-8-7325-2008, 2008.

Laube, J. C., Engel, A., Bönisch, H., Möbius, T., Sturges, W. T., Braß, M., and Röckmann, T.: Fractional release factors of long-lived halogenated organic compounds in the tropical stratosphere, Atmos. Chem. Phys., 10, 1093-1103, doi:10.5194/acp10-1093-2010, 2010.

Logan, J. A.: An analysis of ozonesonde data for the lower stratosphere: Recommendations for testing models, J. Geophys. Res., 104, 16151-16170, 1999.

Marcy, T. P., Fahey, D. W., Gao, R. S., Popp, P. J., Richard, E. C., Thompson, T. L., Rosenlof, K. H., Ray, E. A., Salawitch, R. J., Atherton, C. S., Bergmann, D. J., Ridley, B. A., Weinheimer, A. J., Loewenstein, M., Weinstock, E. M., and Mahoney, M. J.: Quantifying stratospheric ozone in the upper troposphere with in situ measurements of HCl, Science, 304, 261-265, 2004.

Mari, C., Jacob, D. J., and Bechthold, P.: Transport and scavenging of soluble gases in a deep convective cloud, J. Geophys. Res., 105(D17), 22255-22268, 2000.

McKenna, D. S., Grooß, J. U., Günther, G., Konopka, P., Müller, R., Carver, G., and Sasano, Y.: A new Chemical Lagrangian Model of the Stratosphere (CLaMS) - 2. Formulation of chemistry scheme and initialization, J. Geophys. Res., 107, 4256, doi:10.1029/2000JD000113, 2002a.

McKenna, D. S., Konopka, P., Grooß, J. U., Günther, G., Müller, R., Spang, R., Offermann, D., and Orsolini, Y.: A new Chem- 
ical Lagrangian Model of the Stratosphere (CLaMS) - 1. Formulation of advection and mixing, J. Geophys. Res., 107, 4309, doi:10.1029/2000JD000114, 2002b.

Mébarki, Y., Catoire, V., Huret, N., Berthet, G., Robert, C., and Poulet, G.: More evidence for very short-lived substance contribution to stratospheric chlorine inferred from $\mathrm{HCl}$ balloon-borne in situ measurements in the tropics, Atmos. Chem. Phys., 10, 397-409, doi:10.5194/acp-10-397-2010, 2010.

Michelson, H. A., Manney, G. L., Gunson, M. R., and Zander, R.: Correlations of stratospheric abundances of $\mathrm{NO}_{\mathrm{y}}, \mathrm{O}_{3}, \mathrm{~N}_{2} \mathrm{O}$, and $\mathrm{CH}_{4}$ derived from ATMOS measurements, J. Geophys. Res., 103, 28347-28359, 1998.

Möhler, O., Buttner, S., Linke, C., Schnaiter, M., Saathoff, H., Stetzer, O., Wagner, R., Krämer, M., Mangold, A., Ebert, V., and Schurath, U.: Effect of sulfuric acid coating on heterogeneous ice nucleation by soot aerosol particles, J. Geophys. Res., 110, D11210, doi:10.1029/2004JD005169, 2005.

Müller, R., Peter, T., Crutzen, P. J., Oelhaf, H., Adrian, G. P., Vonclarmann, T., Wegner, A., Schmidt, U., and Lary, D.: Chlorine Chemistry and the Potential For Ozone Depletion in the Arctic Stratosphere in the Winter of 1991/92, Geophys. Res. Lett., 21, 1427-1430, 1994.

Nassar, R., Bernath, P. F., Boone, C. D., Clerbaux, C., Coheur, P. F., Dufour, G., Froidevaux, L., Mahieu, E., McConnell, J. C., McLeod, S. D., Murtagh, D. P., Rinsland, C. P., Semeniuk, K., Skelton, R., Walker, K. A., and Zander, R.: A global inventory of stratospheric chlorine in 2004, J. Geophys. Res., 111, D22312, doi:10.1029/2006JD007395, 2006.

Nickolaisen, S. L., Friedl, R. R., and Sander, S. P.: Kinetics and Mechanism of the $\mathrm{ClO}+\mathrm{ClO}$ Reaction - Pressure and Temperature Dependences of the Bimolecular and Termolecular Channels and Thermal-Decomposition of Chlorine Peroxide, J. Phys. Chem., 98(1), 155-169, 1994.

Plenge, J., Flesch, R., Kühl, S., Vogel, B., Müller, R., Stroh, F., and Rühl, E.: Ultraviolet photolysis of the $\mathrm{ClO}$ dimer, J. Phys. Chem., 108(22), 4859-4863, 2004.

Pszenny, A. A. P., Keene, W. C., Jacob, D. J., Fan, S., Maben, J. R., Zetwo, M. P., Springeryoung, M., and Galloway, J. N.: Evidence of Inorganic Chlorine Gases Other Than Hydrogen-Chloride in Marine Surface Air, Geophys. Res. Lett., 20, 699-702, 1993.

Ramaswamy, V., Chanin, M. L., Angell, J., Barnett, J., Gaffen, D., Gelman, M., Keckhut, P., Koshelkov, Y., Labitzke, K., Lin, J. J. R., O’Neill, A., Nash, J., Randel, W., Rood, R., Shine, K., Shiotani, M., and Swinbank, R.: Stratospheric temperature trends: Observations and model simulations, Rev. Geophys., 39, 71-122, 2001.

Salawitch, R. J., Weisenstein, D. K., Kovalenko, L. J., Sioris, C. E., Wennberg, P. O., Chance, K., Ko, M. K. W., and McLinden, C. A.: Sensitivity of ozone to bromine in the lower stratosphere, Geophys. Res. Lett., 32, L05811, doi:10.1029/2004GL021504, 2005.

Salawitch, R. J., Canty, T., Kurosu, T., Chance, K., Liang, Q., da Silva, A., Pawson, S., Nielsen, J. E., Rodriguez, J. M., Bhartia, P. K., Liu, X., Huey, L. G., Liao, J., Stickel, R. E., Tanner, D. J., Dibb, J. E., Simpson, W. R., Donohoue, D., Weinheimer, A., Flocke, F., Knapp, D., Montzka, D., Neuman, J. A., Nowak, J. B., Ryerson, T. B., Oltmans, S., Blake, D. R., Atlas, E. L., Kinnison, D. E., Tilmes, S., Pan, L. L., Hendrick, F., Van Roozendael, M., Kreher, K., Johnston, P. V., Gao, R. S., Johnson, B., Bui, T.
P., Chen, G., Pierce, R. B., Crawford, J. H., and Jacob, D. J.: A new interpretation of total column BrO during Arctic spring, Geophys. Res. Lett., 37, L21805, doi:10.1029/2010GL043798, 2010.

Salby, M. L. and Callaghan, P. F.: Systematic changes of northern hemisphere ozone and their relationship to random interannual changes, J. Quant. Spectrosc. Ra., 17, 4512-4521, 2004.

Sander, S. P., Finlayson-Pitts, B. J., Friedl, R. R., Golden, D. M., Huie, R. E., Keller-Rudek, H., Kolb, C. E., Kurylo, M. J., Molina, M. J., Moortgat, G. K., Orkin, V. L., Ravishankara, A. R., and Wine, P. H.: Chemical Kinetics and Photochemical Data for Use in Atmospheric Studies, Jet Propulsion Laboratory, Pasadena, 06-2, 2006.

Schiller, C., Krämer, M., Afchine, A., Spelten, N., and Sitnikov, N.: Ice water content of Arctic, midlatitude, and tropical cirrus, J. Geophys. Res., 113, D24208, doi:10.1029/2008JD010342, 2008.

Schiller, C., Grooß, J.-U., Konopka, P., Plöger, F., Silva dos Santos, F. H., and Spelten, N.: Hydration and dehydration at the tropical tropopause, Atmos. Chem. Phys., 9, 9647-9660, doi:10.5194/acp-9-9647-2009, 2009.

Schmitt, J.: Construction and testing of an in-situ NO/NO $\mathrm{N}_{\mathrm{y}}$ measuring system aboard the high-altitude research aircaft M55Geophysica, PhD thesis, University of Munich, 2003.

Schwab, J. J. and Anderson, J. G.: Oscillator Strength of $\mathrm{Cl}(\mathrm{I})$ in the Vacuum Ultraviolet: The 2D-2P Transitions, J. Quant. Spectrosc. Ra., 27, 445-457, 1982.

Shi, Q., Jayne, J. T., Kolb, C. E., Worsnop, D. R., and Davidovits, P.: Kinetic model for reaction of $\mathrm{ClONO}_{2}$ with $\mathrm{H}_{2} \mathrm{O}$ and $\mathrm{HCl}$ and $\mathrm{HOCl}$ with $\mathrm{HCl}$ in sulfuric acid solutions, J. Geophys. Res., 106, 24259-24274, 2001.

Sitnikov, N. M., Yushkov, V. A., Afchine, A. A., Korshunov, L. I., Astakhov, V. I., Ulanovskii, A. E., Kraemer, M., Mangold, A., Schiller, C., and Ravegnani, F.: The FLASH instrument for water vapor measurements on board the high-altitude airplane, Instr. Exp. Tech., 50, 113-121, 2007.

Solomon, S., Garcia, R. R., Rowland, F. S., and Wuebbles, D. J.: On the Depletion of Antarctic Ozone, Nature, 321, 755-758, 1986.

Solomon, S., Borrmann, S., Garcia, R. R., Portmann, R., Thomason, L., Poole, L. R., Winker, D., and McCormick, M. P.: Heterogeneous chlorine chemistry in the tropopause region, J. Geophys. Res., 102, 21411-21429, 1997.

Stimpfle, R. M., Perry, R. A., and Howard, C. J.: TemperatureDependence of the Reaction of $\mathrm{ClO}$ and $\mathrm{HO}_{2}$ Radicals, J. Chem. Phys., 71, 5183-5190, 1979.

Stroh, F., Grooß, J.-U., von Hobe, M., Hrechanyy, S., and Winkler, U.: Enhanced $\mathrm{ClO}$ Mixing ratios in the arctic polar winter UTLS region, XX Quadrennial Ozone Symposium, Kos, Greece, 724, 2004.

Thornton, B. F., Toohey, D. W., Avallone, L. M., Harder, H., Martinez, M., Simpas, J. B., Brune, W. H., and Avery, M. A.: In situ observations of $\mathrm{ClO}$ near the winter polar tropopause, J. Geophys. Res., 108, 8333, doi:10.1029/2002JD002839, 2003.

Thornton, B. F., Toohey, D. W., Avallone, L. M., Hallar, A. G., Harder, H., Martinez, M., Simpas, J. B., Brune, W. H., Koike, M., Kondo, Y., Takegawa, N., Anderson, B. E., and Avery, M. A.: Variability of active chlorine in the lowermost Arctic stratosphere, J. Geophys. Res., 110, D22304, doi:10.1029/2004JD005580, 2005.

Ulanovsky, A. E., Yushkov, V. A., Sitnikov, N. M., and Raveng- 
nani, F.: The FOZAN-II fast-response chemiluminescent airborne ozone analyzer, Instrum. Exp. Tech., 44, 249-256, 2001.

Voigt, C., Schlager, H., Luo, B. P., Dörnbrack, A., Roiger, A., Stock, P., Curtius, J., Vössing, H., Borrmann, S., Davies, S., Konopka, P., Schiller, C., Shur, G., and Peter, T.: Nitric Acid Trihydrate (NAT) formation at low NAT supersaturation in Polar Stratospheric Clouds (PSCs), Atmos. Chem. Phys., 5, 13711380, doi:10.5194/acp-5-1371-2005, 2005.

Voigt, C., Kärcher, B., Schlager, H., Schiller, C., Krämer, M., de Reus, M., Vössing, H., Borrmann, S., and Mitev, V.: In-situ observations and modeling of small nitric acid-containing ice crystals, Atmos. Chem. Phys., 7, 3373-3383, doi:10.5194/acp7-3373-2007, 2007.

von Clarmann, T., Glatthor, N., Ruhnke, R., Stiller, G. P., Kirner, O., Reddmann, T., Höpfner, M., Kellmann, S., Kouker, W., Linden, A., and Funke, B.: HOCl chemistry in the Antarctic Stratospheric Vortex 2002, as observed with the Michelson Interferometer for Passive Atmospheric Sounding (MIPAS), Atmos. Chem. Phys., 9, 1817-1829, doi:10.5194/acp-9-1817-2009, 2009.

von Hobe, M., Grooß, J.-U., Müller, R., Hrechanyy, S., Winkler, U., and Stroh, F.: A re-evaluation of the $\mathrm{ClO} / \mathrm{Cl}_{2} \mathrm{O}_{2}$ equilibrium constant based on stratospheric in-situ observations, Atmos. Chem. Phys., 5, 693-702, doi:10.5194/acp-5-693-2005, 2005.

von Hobe, M., Salawitch, R. J., Canty, T., Keller-Rudek, H., Moortgat, G. K., Grooß, J.-U., Müller, R., and Stroh, F.: Understanding the kinetics of the $\mathrm{ClO}$ dimer cycle, Atmos. Chem. Phys., 7, 3055-3069, doi:10.5194/acp-7-3055-2007, 2007.

Wang, P. H., Minnis, P., McCormick, M. P., Kent, G. S., and Skeens, K. M.: A 6-year climatology of cloud occurrence frequency from Stratospheric Aerosol and Gas Experiment II observations (1985-1990), J. Geophys. Res., 101, 29407-29429, 1996.
Weigel, R., Hermann, M., Curtius, J., Voigt, C., Walter, S., Böttger, T., Lepukhov, B., Belyaev, G., and Borrmann, S.: Experimental characterization of the COndensation PArticle counting System for high altitude aircraft-borne application, Atmos. Meas. Tech., 2, 243-258, doi:10.5194/amt-2-243-2009, 2009.

WMO: Scientific assessment of ozone depletion, World Meteorological Organization, Global ozone research and monitoring project, Geneva, Switzerland 50, 2006.

Woodbridge, E. L., Elkins, J. W., Fahey, D. W., Heidt, L. E., Solomon, S., Baring, T. J., Gilpin, T. M., Pollock, W. H., Schauffler, S. M., Atlas, E. L., Loewenstein, M., Podolske, J. R., Webster, C. R., May, R. D., Gilligan, J. M., Montzka, S. A., Boering, K. A., and Salawitch, R. J.: Estimates of Total Organic and Inorganic Chlorine in the Lower Stratosphere From in-Situ and Flask Measurements During Aase-Ii, J. Geophys. Res., 100, 3057-3064, 1995.

Yushkov, V., Oulanovsky, A., Lechenuk, N., Roudakov, I., Arshinov, K., Tikhonov, F., Stefanutti, L., Ravegnani, F., Bonafe, U., and Georgiadis, T.: A chemiluminescent analyzer for stratospheric measurements of the ozone concentration (FOZAN), J. Atmos. Ocean. Technol., 16, 1345-1350, 1999.

Zhang, R. Y., Leu, M. T., and Keyser, L. F.: Heterogeneous Reactions of $\mathrm{ClONO}_{2}, \mathrm{HCl}$, and $\mathrm{HOCl}$ On Liquid Sulfuric-Acid Surfaces, J. Phys. Chem., 98, 13563-13574, 1994.

Zöger, M., Afchine, A., Eicke, N., Gerhards, M. T., Klein, E., McKenna, D. S., Morschel, U., Schmidt, U., Tan, V., Tuitjer, F., Woyke, T., and Schiller, C.: Fast in situ stratospheric hygrometers: A new family of balloon-borne and airborne Lyman alpha photofragment fluorescence hygrometers, J. Geophys. Res., 104, 1807-1816, 1999. 